Cochrane Database of Systematic Reviews

\title{
Ketogenic diets for drug-resistant epilepsy (Review)
}

Martin-McGill KJ, Jackson CF, Bresnahan R, Levy RG, Cooper PN

Martin-McGill KJ, Jackson CF, Bresnahan R, Levy RG, Cooper PN.

Ketogenic diets for drug-resistant epilepsy.

Cochrane Database of Systematic Reviews 2018, Issue 11. Art. No.: CD001903.

DOI: 10.1002/14651858.CD001903.pub4.

www.cochranelibrary.com 
TABLE OF CONTENTS

HEADER 1

ABSTRACT

PLAIN LANGUAGE SUMMARY

SUMMARY OF FINDINGS

BACKGROUND

OBJECTIVES

METHODS

RESULTS

Figure 1.

Figure 2.

Figure 3.

DISCUSSION

AUTHORS' CONCLUSIONS

ACKNOWLEDGEMENTS

REFERENCES

CHARACTERISTICS OF STUDIES

APPENDICES

WHAT'S NEW

HISTORY

CONTRIBUTIONS OF AUTHORS

DECLARATIONS OF INTEREST

SOURCES OF SUPPORT

DIFFERENCES BETWEEN PROTOCOL AND REVIEW

INDEX TERMS 
[Intervention Review]

\section{Ketogenic diets for drug-resistant epilepsy}

Kirsty J Martin-McGill1,2, Cerian F Jackson¹, Rebecca Bresnahan¹, Robert G Levy³, Paul N Cooper4

1Department of Molecular and Clinical Pharmacology, Institute of Translational Medicine, University of Liverpool, Liverpool, UK.

${ }^{2}$ Dietetics Office, The Walton Centre NHS Foundation Trust, Liverpool, UK. ${ }^{3}$ The Croft Shifta Health Centre, Rochdale, UK. ${ }^{4}$ Centre for

Clinical Neurosciences, Salford Royal Hospitals NHS Trust, Salford, UK

Contact address: Kirsty J Martin-McGill, Department of Molecular and Clinical Pharmacology, Institute of Translational Medicine, University of Liverpool, Lower Lane, Liverpool, L9 7LJ, UK. kirsty.martin@liverpool.ac.uk.

Editorial group: Cochrane Epilepsy Group

Publication status and date: New search for studies and content updated (no change to conclusions), published in Issue 11, 2018.

Citation: Martin-McGill KJ, Jackson CF, Bresnahan R, Levy RG, Cooper PN. Ketogenic diets for drug-resistant epilepsy. Cochrane Database of Systematic Reviews 2018, Issue 11. Art. No.: CD001903. DOI: 10.1002/14651858.CD001903.pub4.

Copyright @ 2018 The Cochrane Collaboration. Published by John Wiley \& Sons, Ltd.

\section{A B S T R A C T}

\section{Background}

Ketogenic diets (KDs), being high in fat and low in carbohydrates, have been suggested to reduce seizure frequency in people with epilepsy. At present, such diets are mainly recommended for children who continue to have seizures despite treatment with antiepileptic drugs (AEDs) (drug-resistant epilepsy). Recently, there has been interest in less restrictive KDs, including the modified Atkins diet (MAD), and the use of these diets has extended into adult practice. This is an update of a review first published in 2003 and last updated in 2016.

\section{Objectives}

To assess the effects of KDs for drug-resistant epilepsy by reviewing the evidence from randomised controlled trials.

\section{Search methods}

For the latest update we searched the Cochrane Epilepsy Group's Specialized Register (11 April 2017), the Cochrane Central Register of Controlled Trials (CENTRAL) via the Cochrane Register of Studies Online (CRSO, 11 April 2017), MEDLINE (Ovid, 11 April 2017), ClinicalTrials.gov (11 April 2017) and the WHO International Clinical Trials Registry Platform (ICTRP, 11 April 2017). We imposed no language restrictions. We checked the reference lists of retrieved studies for additional reports of relevant studies.

\section{Selection criteria}

Randomised controlled trials or quasi-randomised controlled trials of ketogenic diets for people with drug-resistant epilepsy.

\section{Data collection and analysis}

Two review authors independently applied predefined criteria to extract data and assessed study quality.

\section{Main results}

We identified 11 randomised controlled trials (RCTs) that generated 15 publications.

All trials applied an intention-to-treat analysis with varied randomisation methods. The 11 studies recruited 778 patients; 712 children and adolescents and 66 adults. We assessed all 11 studies to be at low to unclear risk of bias for the following domains: random sequence generation, allocation concealment and selective reporting. For the other domains (blinding, incomplete outcome data, other bias) assessments were varied (low, unclear and high risk of bias). We could not conduct a meta-analysis due to the heterogeneity of the studies and the quality of the evidence was low to very low (GRADE ratings). 
Reported rates of seizure freedom reached as high as 55\% in a classical 4:1 KD group after three months and reported rates of seizure reduction reached as high as $85 \%$ in a classical 4:1 KD group after three months (GRADE rating low).

One trial found no significant difference between the fasting-onset and gradual-onset KD for rates of seizure freedom, and reported a greater rate of seizure reduction in the gradual-onset KD group.

Studies assessing the efficacy of the MAD reported seizure freedom rates of up to $25 \%$ and seizure reduction rates of up to $60 \%$ in children. One study used a simplified MAD (SMAD) and reported seizure freedom rates of $15 \%$ and seizure reduction rates of $56 \%$ in children. One study utilised a MAD in adults and reported seizure reduction rates of $35 \%$, but no patients became seizure free (GRADE rating low).

Adverse effects of the dietary interventions were experienced in all studies. The most commonly reported adverse effects were gastrointestinal syndromes. It was common that adverse effects were the reason for participants dropping out of trials (GRADE rating low). Other reasons for dropout included lack of efficacy and non-acceptance of the diet (GRADE rating low).

Although there was some evidence for greater antiepileptic efficacy for a classical 4:1 KD over lower ratios, the classical 4:1 KD was consistently associated with more adverse effects.

One study assessed the effect of dietary interventions on quality of life, cognition and behavioural functioning, reporting participants in the KD group to be more active, more productive and less anxious after four months, compared to the control group. However, no significant difference was found in quality-adjusted life years (QALYs) between the KD group and control group at four or 16 months (GRADE rating very low).

\section{Authors' conclusions}

The RCTs discussed in this review show promising results for the use of KDs in epilepsy. However, the limited number of studies, small sample sizes and the limited studies in adults, resulted in a low to very low overall quality of evidence.

There were adverse effects within all of the studies and for all KD variations, such as short-term gastrointestinal-related disturbances and increased cholesterol. However, study periods were short, therefore the long-term risks associated with these adverse effects is unknown. Attrition rates remained a problem with all KDs and across all studies; reasons for this being lack of observed efficacy and dietary tolerance.

Only one study reported the use of KDs in adults with epilepsy; therefore further research would be of benefit.

Other more palatable but related diets, such as the MAD, may have a similar effect on seizure control as the classical KD, but this assumption requires more investigation. For people who have medically intractable epilepsy or people who are not suitable for surgical intervention, KDs remain a valid option; however, further research is required.

\section{PLAIN LANGUAGE SUMMARY}

\section{Ketogenic diets for drug-resistant epilepsy}

\section{Background}

Epilepsy is a disorder where recurrent seizures (fits) are caused by abnormal electrical discharges from the brain. In most people seizures can be controlled by one or more antiepileptic medicines, but seizures may not be helped by these medicines after a while (called drugresistant epilepsy). For people who have drug-resistant epilepsy, a special diet (called a ketogenic diet) may be considered. Ketogenic diets are high in fat and low in carbohydrate.

This review aimed to investigate the effect of ketogenic diets on seizure control, cognition (e.g. learning, concentration and academic performance in children; learning, concentration and memory in adults) and behaviour. We also investigated the side effects of the diet and the number of participants who dropped out of the studies and the reasons for this.

\section{Study characteristics}

We searched medical databases for randomised controlled trials (clinical studies where people are randomly put into one of two or more treatment groups) of adults or children with epilepsy, where a ketogenic diet was compared with other treatments. We found 11 randomised controlled trials, with 778 participants. The trials were between two and 16 months long.

\section{Key results}

The short-term side effects of ketogenic diets included diarrhoea, constipation and vomiting. Long-term effects are unknown from these studies.

All studies reported participants dropping out, due to lack of improvement in seizures and poor tolerance of the diet. 
One study reported upon the effect of ketogenic diets on quality of life, cognition and behaviour. No difference was found in the quality of life of those following a ketogenic diet and the group receiving care as usual, but participants following the ketogenic diet were found to be more active, more productive and less anxious. More research is needed in these areas.

Recently, other, better tolerated, ketogenic diets, such as the modified Atkins diet, found similar effects on seizure control as those more restrictive ketogenic diets. However, more research is required.

\section{Quality of the evidence}

The studies included in this review were limited by small numbers of participants and only children were included in 10 of the 11 studies, therefore, we judged the quality of the evidence to be low to very low.

There is little research at present into the use of these diets in adults, therefore, more research is required in this area.

This evidence is current to April 2017. 
SUMMARY OF FINDINGS

\section{Summary of findings for the main comparison. Summary of Findings - Ketogenic diets compared to control for people with epilepsy}

\section{Ketogenic diets compared to control for people with epilepsy}

Patient or population: people with epilepsy

Settings: outpatients

Intervention: ketogenic diets

Control: control intervention (care as usual)

\begin{tabular}{|c|c|c|c|c|c|c|}
\hline \multirow[t]{3}{*}{ Outcomes } & \multicolumn{2}{|c|}{ Illustrative comparative risks* $(95 \% \mathrm{Cl})$} & \multirow{3}{*}{$\begin{array}{l}\text { Relative ef- } \\
\text { fect } \\
(95 \% \mathrm{Cl})\end{array}$} & \multirow{3}{*}{$\begin{array}{l}\text { No. of partic- } \\
\text { ipants } \\
\text { (studies) }\end{array}$} & \multirow{3}{*}{$\begin{array}{l}\text { Quality of the } \\
\text { evidence } \\
\text { (GRADE) }\end{array}$} & \multirow[t]{3}{*}{ Comments } \\
\hline & Assumed risk & Corresponding risk & & & & \\
\hline & Control & Ketogenic diets & & & & \\
\hline $\begin{array}{l}\text { Seizure freedom } \\
\text { (100\% reduction in } \\
\text { seizure frequency) } \\
\text { Follow-up: } 2 \text { months } \\
\text { to } 12 \text { months }\end{array}$ & $\begin{array}{l}\text { Proportion of individuals achiev- } \\
\text { ing seizure freedom ranged from } \\
0 \% \text { to } 9 \% \text { in the control groups }\end{array}$ & $\begin{array}{l}\text { Proportion of individuals achiev- } \\
\text { ing seizure freedom ranged from } \\
0 \% \text { to } 15 \% \text { in the KD groups }\end{array}$ & Not estimable & $\begin{array}{l}350 \\
\text { (4 studies) }\end{array}$ & $\begin{array}{l}\oplus \oplus \ominus \ominus \\
\text { Low }^{1,2}\end{array}$ & $\begin{array}{l}\text { No studies reported a } \\
\text { statistically significant } \\
\text { difference between KD } \\
\text { and control. }\end{array}$ \\
\hline $\begin{array}{l}\text { Seizure reduction } \\
\text { ( } 50 \% \text { or greater re- } \\
\text { duction in seizure } \\
\text { frequency) } \\
\text { Follow-up: } 2 \text { months } \\
\text { to } 16 \text { months }\end{array}$ & $\begin{array}{l}\text { Proportion of individuals achiev- } \\
\text { ing } 50 \% \text { or greater reduction in } \\
\text { seizure frequency ranged from } \\
0 \% \text { to } 18 \% \text { in the control groups }\end{array}$ & $\begin{array}{l}\text { Proportion of individuals achiev- } \\
\text { ing } 50 \% \text { or greater reduction in } \\
\text { seizure frequency ranged from } \\
35 \% \text { to } 56 \% \text { in the KD groups }\end{array}$ & Not estimable & $\begin{array}{l}452 \\
\text { (5 studies) }\end{array}$ & $\begin{array}{l}\oplus \oplus \oplus \ominus \\
\text { Low }^{1,2}\end{array}$ & $\begin{array}{l}\text { All five studies report- } \\
\text { ed a statistically signif- } \\
\text { icant advantage to the } \\
\text { KD group over the con- } \\
\text { trol group. }\end{array}$ \\
\hline $\begin{array}{l}\text { Adverse effects } \\
\text { Follow-up: } 2 \text { months } \\
\text { to } 16 \text { months }\end{array}$ & \multicolumn{2}{|c|}{$\begin{array}{l}\text { The most frequent adverse effects reported by participants in di- } \\
\text { etary intervention groups were: vomiting and constipation. Other } \\
\text { adverse effects reported included diarrhoea, dysphagia, lethargy, } \\
\text { lower respiratory tract infection, hyperammonaemic encephalopa- } \\
\text { thy, weight loss, nausea, infections (pneumonia, sepsis), acute pan- } \\
\text { creatitis, decrease in bone matrix density, gallstones, fatty liver, } \\
\text { nephrocalcinosis, hypercholesterolaemia, status epilepticus, acido- } \\
\text { sis, dehydration, tachycardia, hypoglycaemia, hunger,abdominal } \\
\text { pain, clinically relevant reduction in height, hypercalcinaemia and } \\
\text { renal stones. }\end{array}$} & Not estimable & $\begin{array}{l}452 \\
\text { (5 studies) }\end{array}$ & $\begin{array}{l}\oplus \oplus \oplus \ominus \\
\text { Low }^{1,2}\end{array}$ & $\begin{array}{l}\text { Few statistically signif- } \\
\text { icant differences were } \\
\text { found between the KD } \\
\text { groups and control } \\
\text { groups. }\end{array}$ \\
\hline
\end{tabular}




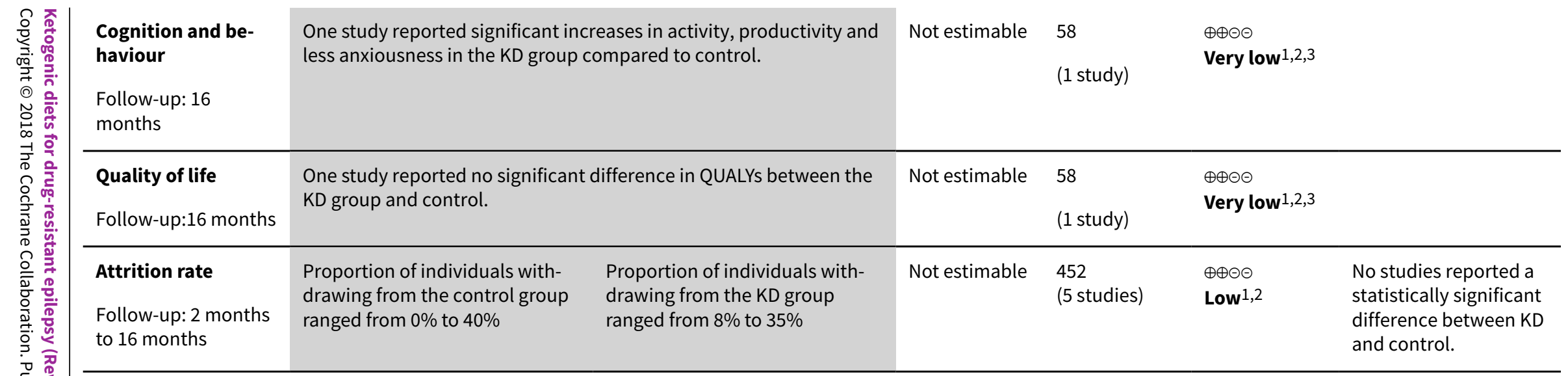

${ }^{\star}$ The basis for the assumed risk (e.g. the median control group risk across studies) is provided in footnotes. The corresponding risk (and its $95 \%$ confidence interval) is based on the assumed risk in the comparison group and the relative effect of the intervention (and its $95 \% \mathrm{Cl}$ ).

Cl: confidence interval; KD: ketogenic diet;QUALYs: quality-adjusted life years.

\section{GRADE Working Group grades of evidence}

High quality: further research is very unlikely to change our confidence in the estimate of effect.

Moderate quality: further research is likely to have an important impact on our confidence in the estimate of effect and may change the estimate.

Low quality: further research is very likely to have an important impact on our confidence in the estimate of effect and is likely to change the estimate.

Very low quality: we are very uncertain about the estimate.

1Downgraded once due to inconsistency: studies are heterogeneous with regards to interventions examined and comparisons made.

2Downgraded once due to risk of bias: some included studies were not blinded, had missing data or unclear methodological details reported.

${ }^{3}$ Downgraded once due to imprecision: low overall sample size. Confidence in results from small number of participants is low.

\section{Summary of findings 2. Summary of findings - Ketogenic diets compared with other ketogenic diets for people with epilepsy}

Ketogenic diets compared with other ketogenic diets for people with epilepsy

Patient or population: people with epilepsy

Settings: outpatients

Intervention: ketogenic diets

Control: other ketogenic diets

\begin{tabular}{|c|c|c|c|c|c|c|}
\hline \multirow[t]{2}{*}{ Outcomes } & \multicolumn{2}{|c|}{ Illustrative comparative risks ${ }^{\star}(95 \% \mathrm{CI})$} & \multirow{2}{*}{$\begin{array}{l}\text { Relative ef- } \\
\text { fect } \\
(95 \% \mathrm{Cl})\end{array}$} & \multirow{2}{*}{$\begin{array}{l}\text { No. of Partic- } \\
\text { ipants } \\
\text { (studies) }\end{array}$} & \multirow{2}{*}{$\begin{array}{l}\text { Quality of the } \\
\text { evidence } \\
\text { (GRADE) }\end{array}$} & \multirow[t]{2}{*}{ Comments } \\
\hline & Assumed risk & Corresponding risk & & & & \\
\hline
\end{tabular}




\begin{tabular}{|c|c|c|c|c|c|}
\hline & Other Ketogenic Diets & & & & \\
\hline $\begin{array}{l}\text { Seizure freedom } \\
\text { (100\% reduction in } \\
\text { seizure frequency) } \\
\text { Follow-up: } 3 \text { months to } \\
6 \text { months }\end{array}$ & $\begin{array}{l}\text { Proportion of individuals achieving seizure freedom ranged from } \\
10 \% \text { to } 25 \% \text { on MAD: } 21 \% \text { on } 2: 5: 1 \mathrm{KD} \text {, fasting-onset KD and grad- } \\
\text { ual-onset KD, ranged from } 26 \% \text { to } 55 \% \text { on } 4: 1 \mathrm{KD}, 33 \% \text { on the classic } \\
\mathrm{KD} \text {, and } 35 \% \text { on the } 3: 1 \mathrm{KD}\end{array}$ & Not estimable & $\begin{array}{l}286 \\
\text { (5 studies) }\end{array}$ & $\begin{array}{l}\oplus \oplus \Theta \odot \\
\text { Very low } 1,2,3\end{array}$ & \\
\hline $\begin{array}{l}\text { Seizure reduction } \\
\text { ( } 50 \% \text { or greater reduc- } \\
\text { tion in seizure frequen- } \\
\text { cy) } \\
\text { Follow-up: } 3 \text { months to } \\
6 \text { months }\end{array}$ & $\begin{array}{l}\text { Proportion of individuals achieving seizure freedom ranged from } \\
42 \% \text { to } 60 \% \text { on MAD: } 43 \% \text { on the classic } K D, 58 \% \text { on the fasting-on- } \\
\text { set } \mathrm{KD} \text {, ranged from } 58 \% \text { to } 85 \% \text { on } 4: 1 \mathrm{KD}, 63 \% \text { on } 2: 5: 1 \mathrm{KD}, 67 \% \text { on } \\
\text { the gradual-onset } \mathrm{KD} \text {, and } 72 \% \text { on the } 3: 1 \mathrm{KD}\end{array}$ & Not estimable & $\begin{array}{l}326 \\
\text { (6 studies) }\end{array}$ & $\begin{array}{l}\oplus \oplus \ominus \ominus \\
\text { Very low } 1,2,3\end{array}$ & $\begin{array}{l}\text { One study reported } \\
\text { a statistically signif- } \\
\text { icant advantage for } \\
10 \mathrm{~g} \text { carbohydrate } \\
\text { MAD over } 20 \mathrm{~g} \text { carbo- } \\
\text { hydrate MAD } \\
\text { One study reported } \\
\text { no significant differ- } \\
\text { ence between classic } \\
\text { KD and MAD } \\
\text { One study reported } \\
\text { no significant differ- } \\
\text { ence between } 4: 1 \mathrm{KD} \\
\text { and } 2: 5: 1 \mathrm{KD}\end{array}$ \\
\hline $\begin{array}{l}\text { Adverse effects } \\
\text { Follow-up: } 3 \text { months to } \\
6 \text { months }\end{array}$ & $\begin{array}{l}\text { The most frequent adverse effects reported by participants in di- } \\
\text { etary intervention groups were: vomiting and constipation. Other } \\
\text { adverse effects reported included diarrhoea, dysphagia, lethargy, } \\
\text { lower respiratory tract infection, hyperammonaemic encephalopa- } \\
\text { thy, weight loss, nausea, infections (pneumonia, sepsis), acute pan- } \\
\text { creatitis, decrease in bone matrix density, gallstones, fatty liver, } \\
\text { nephrocalcinosis, hypercholesterolaemia, status epilepticus, acido- } \\
\text { sis, dehydration, tachycardia, hypoglycaemia, hunger,abdominal } \\
\text { pain, clinically relevant reduction in height, hypercalcinaemia and } \\
\text { renal stones. }\end{array}$ & Not estimable & $\begin{array}{l}326 \\
\text { (6 studies) }\end{array}$ & $\begin{array}{l}\oplus \oplus \Theta \odot \\
\text { Very low } 1,2,3\end{array}$ & $\begin{array}{l}\text { Few statistically sig- } \\
\text { nificant differences } \\
\text { were found between } \\
\text { KD groups }\end{array}$ \\
\hline $\begin{array}{l}\text { Cognition and behav- } \\
\text { iour } \\
\text { Follow-up: NA }\end{array}$ & Outcome not reported & & & NA & \\
\hline $\begin{array}{l}\text { Quality of life } \\
\text { Follow-up: NA }\end{array}$ & Outcome not reported & & & NA & \\
\hline
\end{tabular}


*The basis for the assumed risk (e.g. the median control group risk across studies) is provided in footnotes. The corresponding risk (and its $95 \%$ confidence interval) is based on the assumed risk in the comparison group and the relative effect of the intervention (and its $95 \% \mathrm{Cl}$ ).

Cl: confidence interval; KD: ketogenic diet;MAD: modified Atkins diet; MCT: medium-chain triglyceride; NA: not applicable.

GRADE Working Group grades of evidence

High quality: further research is very unlikely to change our confidence in the estimate of effect.

Moderate quality: further research is likely to have an important impact on our confidence in the estimate of effect and may change the estimate.

Low quality: further research is very likely to have an important impact on our confidence in the estimate of effect and is likely to change the estimate.

Very low quality: we are very uncertain about the estimate.

${ }^{1}$ Downgraded once due to inconsistency: studies are heterogeneous with regards to interventions examined and comparisons made.

2Downgraded once due to risk of bias: some included studies were not blinded, had missing data or unclear methodological details reported.

3Downgraded once due to applicability: included studies recruited children and young people under the age of 18 , therefore results are not applicable to adults over the age of 18. 


\section{B A C K G R O U N D}

\section{Description of the condition}

Epilepsy is a common treatable neurological condition with a lifetime risk of $1 \%$ to $3 \%$ (Hauser 1990). It is characterised by recurrent involuntary brain activity that manifests in seizures (Chang 2003). Although the majority of people with epilepsy will have a good response and become seizure free by treatment with antiepileptic drugs (AEDs), approximately $30 \%$ of people with epilepsy will continue to have seizures even when taking multiple AEDs (drug-resistant epilepsy) (Granata 2009). Uncontrolled seizures pose a significant risk to quality of life (Lawn 2004; Schmidt 2002; Villeneuve 2004). In addition, uncontrolled tonicclonic seizures are likely to be one of the strongest risk factors of sudden death in epilepsy (Nilsson 1999). Therefore, it is important not to rely on pharmacological interventions when treating drugresistant epilepsy and further evidence for alternative interventions is needed.

\section{Description of the intervention}

Diets have been used in an attempt to control epileptic seizures throughout the centuries, indeed there is a biblical reference to prayer and fasting in epilepsy (St Mark 9: 14-29). Scientific assessment of dietary manipulation reported in Guelpa 1911, and subsequently in Geyelin 1921, confirmed that seizures may cease on absolute fasting, but neither study was a randomised controlled trial (RCT). Wilder 1921 suggested that a diet high in fat and low in carbohydrates would be similar to fasting. The classical ketogenic diet (KD) uses a 4:1 ratio of total energy from fat to carbohydrate and protein combined. KDs have been described as unpalatable and difficult to tolerate, thus leading to poor compliance. Therefore, several diets have been developed to improve palatability, including those of lower ratios (such as 3:1), the medium-chain triglyceride (MCT) KD (Huttenlocher 1971), and the modified Atkins diet (MAD). The MCT KD allows for an increase in carbohydrate and protein due to the potential to increase ketone levels through the inclusion of MCT fats. Whilst the MAD, adapted from the Aktins diet initially used for weight reduction (Atkins 1972), restricts carbohydrate to $10 \mathrm{~g}$ to $20 \mathrm{~g}$ per day, and is considered less restrictive than classical KDs.

Prior to the introduction of anticonvulsant medications (Merritt 1938), the KD was used in children (and adults) who were more representative of the current general population of people with epilepsy. However, case series published since the mid-1980s have generally included people with multiple seizure types drugresistant to multiple AEDs. The classic KD and other more palatable versions have a positive effect on infantile spasms, severe myoclonic epilepsy, tuberous sclerosis complex (Kossoff 2005), and children with drug-resistant status epilepticus (O'Connor 2014).

\section{How the intervention might work}

Although the anticonvulsant effects of KDs remain unclear, numerous biochemical theories have been suggested for the possible action of the diet. These include the anticonvulsant effects of elevated ketone bodies, elevated fatty acids and reduced glucose levels (Bough 2007), with further research ongoing in this field.

\section{Why it is important to do this review}

Despite the use of KDs for adults and children with drug-resistant epilepsy within clinical settings, the number of high-quality RCTs has been limited. Therefore, the evidence base for this intervention has been unclear. This review aims to assess the effectiveness of KDs when considering evidence from RCTs, across all healthcare settings, for both adults and children with drug-resistant epilepsy. RCTs which compare KDs to controls and one KD to another KD will be included in the review.

\section{O B JECTIVES}

To assess the effects of KDs for drug-resistant epilepsy by reviewing the evidence from randomised controlled trials.

\section{METHODS}

\section{Criteria for considering studies for this review \\ Types of studies}

All randomised controlled trials (RCTs) or quasi-RCTs of ketogenic diet (KD) interventions for people with drug-resistant epilepsy, with a minimum study period of one month.

\section{Types of participants}

Adults and children with a diagnosis of drug-resistant epilepsy irrespective of their seizure type or epilepsy syndrome.

\section{Types of interventions}

\section{Ketogenic diet group (related diet)}

- Any diet that is designed to produce ketones. There are several KDs that have been used depending upon the proportion of the different types of lipids. The main types of diet are classical KD, medium-chain triglyceride (MCT) KD, modified Atkins diet (MAD) and low glycaemic index treatment (LGIT). We will also include studies which compare different types of KDs or different KD regimes (fasting versus gradual initiation).

\section{Control group}

- Placebo/usual/sham diet given as a standard treatment that is thought to have no effect on epilepsy.

- Any treatment with known antiepileptic properties.

\section{Types of outcome measures}

\section{Primary outcomes}

- Seizure freedom (100\% reduction in seizure frequency)

- Seizure reduction $(50 \%$ or greater reduction in seizure frequency)

- Adverse effects

\section{Secondary outcomes}

- Cognitive and behaviour outcomes, as measured by validated rating scales

- Quality of life, as measured by validated rating scales

- Attrition rate 


\section{Search methods for identification of studies}

\section{Electronic searches}

Searches were run for the original review in March 2005 and subsequent searches were run in July 2007, January 2010, June 2011, March 2015, and April 2017. For the most recent update of this review we searched:

- the Cochrane Epilepsy Group Specialized Register (11 April 2017) using the search strategy outlined in Appendix 1;

- the Cochrane Central Register of Controlled Trials (CENTRAL) via the Cochrane Register of Studies Online (CRSO, 11 April 2017) using the search strategy outlined in Appendix 2;

- MEDLINE (Ovid, 1946 to 11 April 2017) using the search strategy outlined in Appendix 3;

- ClinicalTrials.gov (11 April 2017) using the search strategy outlined in Appendix 4; and

- the World Health Organization (WHO) International Clinical Trials Registry Platform (ICTRP, 11 April 2017) using the search strategy outlined in Appendix 5.

For the original review we searched Embase from 1980 to March 2003. We no longer have access to that database. However, RCTs and quasi-RCTs in Embase are included in CENTRAL. Therefore, these records are available to us via our searches of CENTRAL.

\section{Searching other resources}

We searched references from previous versions of this review (backward referencing) and newer references from more up-todate studies.

We contacted experts in the area to enquire about other relevant studies.

\section{Data collection and analysis}

\section{Selection of studies}

Two review authors (CJ, KMM) independently reviewed the titles and abstract of the studies identified by the electronic searches and removed studies that did not meet the inclusion criteria. Two review authors (CJ, KMM) reviewed the full-text reports to determine eligibility. We resolved any disagreements by discussion. In the event of there being multiple reports deriving from one study, we linked the reports together.

\section{Data extraction and management}

In addition to the main outcome measures listed in Primary outcomes and Secondary outcomes, three review authors (CJ, $\mathrm{KMM}, \mathrm{RB})$ completed data extraction for each study. We crosschecked results of the data extraction and resolved any disagreements by discussion.

We also collected the following data using a pre-standardised data extraction form.

- Participant characteristics including age, sex and number of participants (randomised to each group).

- Diet intervention (classical or MCT or other).

- Length of follow-up.

- Epilepsy seizure type.

- Reason for commencement.
- Adverse effects

- Reason for dropout, including compliance.

\section{Assessment of risk of bias in included studies}

Three review authors (CJ, KMM, RB) independently assessed the risk of bias and compared the results from these assessments to identify any inconsistencies. We resolved any disagreements by discussion.

We judged whether each study was at high, low or unclear risk of bias in each of the following domains:

1. Random sequence generation;

2. Allocation concealment;

3. Blinding;

4. Incomplete outcome data;

5. Selective outcome reporting.

6. Other potential risks of bias.

Where possible, we planned to incorporate the risk of bias judgement into the analysis using sensitivity analysis. This analysis of the data would have included only studies rated at low risk of bias.

\section{Measures of treatment effect}

Where possible, we presented outcomes as risk ratios (RRs) with 95\% confidence intervals (Cls) and reported secondary outcomes narratively. For behaviour, quality of life and cognitive outcomes, it was unlikely that individual authors would have addressed this in a uniform manner. In the first instance, we planned to summarise the results using text and tables.

\section{Unit of analysis issues}

In the event of unit of analysis issues being identified across studies (e.g. cross-over, cluster randomised or repeated measures studies), we planned to:

- determine whether the methods in such studies were conducted appropriately; and

- combine extracted effect sizes from such studies through a generic inverse variance meta-analysis.

\section{Dealing with missing data}

In the event of missing data, we conducted an intention-to-treat (ITT) analysis where possible, including all allocated participants in the treatment groups to which they were allocated, irrespective of the treatment they received. Where necessary, we contacted original trial authors for additional data or clarification.

\section{Assessment of heterogeneity}

Three review authors (CJ, KMM, RB) assessed clinical and methodological heterogeneity by investigating the distribution of important prognostic factors between trials and the study design. We assessed statistical heterogeneity using a $\mathrm{Chi}^{2}$ test $(P<0.05)$ and an $\mathrm{I}^{2}$ statistic of greater than $50 \%$ to indicate statistical heterogeneity in accordance with Cochrane guidelines (Higgins 2011).

Provided we found no heterogeneity, we planned summary estimates across trials. Our preferred estimator was RRs with 95\% 
Cls calculated using the Mantel-Haenszel method using both fixedeffect and random-effects models.

\section{Assessment of reporting biases}

We investigated outcome reporting bias using the ORBIT matrix system (Kirkham 2010). We requested all protocols from study authors to compare outcomes of interest.

To examine publication bias, we identified any unpublished data by carrying out a comprehensive search of multiple sources and requesting unpublished data from study authors. We planned to examine funnel plots in the event of there being 10 or more studies that could be combined, in accordance with Cochrane recommendations (Higgins 2011).

\section{Data synthesis}

Ideally, we would have presented the data in a fixed-effect metaanalysis; however, as we expected some heterogeneity across the studies, we planned to carry out a random-effects meta-analysis.

We planned to present seizure freedom, seizure reduction by $50 \%$ and adverse effects as RRs with 95\% Cls.

Due to significant clinical and methodological heterogeneity, metaanalysis was not possible and, therefore, we reported the outcomes narratively.

We planned to carry out the following comparisons.

- KD compared with a control (standard of care and usual diet).

- KD compared with other dietary interventions.

- KD compared with other interventions.

- One KD compared with another KD intervention.

We created two 'Summary of findings' tables for all outcomes: KD compared with a control (standard of care and usual diet) (Summary of findings for the main comparison); and KD compared with another KD intervention (Summary of findings 2). We graded each outcome using the GRADE approach (Guyatt 2008) (a formal process used to rate the quality of evidence in systematic reviews).

\section{Subgroup analysis and investigation of heterogeneity}

We stratified results according to method of allocation concealment, e.g. by control group, participant group, study characteristics, or a combination of these to ensure appropriate combination of study data.

\section{Sensitivity analysis}

We intended to carry out sensitivity analysis if we found peculiarities between study quality. We planned to report and compare analyses for only the studies at low risk of bias.

\section{RES U L T S}

\section{Description of studies}

\section{Results of the search}

Previous versions of this review identified seven randomised controlled trials (RCTs) (Bergqvist 2005; El-Rashidy 2013; Kossoff 2007; Neal 2008; Raju 2011; Seo 2007; Sharma 2013), from eight publications (Neal 2009).

The updated search revealed 101 studies from the databases outlined in Electronic searches and four additional studies through other sources. After removing duplicates, 98 studies remained. Initial screening removed 88 irrelevant studies, leaving 10 studies. The remaining studies underwent full-text review after which we excluded a further 3 studies (Dressler 2015; Freeman 2009; Singh 2015), and deemed 7 studies eligible for inclusion in the present review update. Four publications were generated from 1 RCT (de Kinderen 2016; ljff 2016; Lambrechts 2017; Wijnen 2017), therefore the results were merged under Lambrechts 2017. Thus, we included 4 new RCTs in this update (Kim 2016; Lambrechts 2017; Sharma 2016; Zare 2017).

See Figure 1 for a PRISMA study flow diagram (Moher 2009). 
Figure 1. Study flow diagram (results illustrate the latest update).




Figure 1. (Continued)

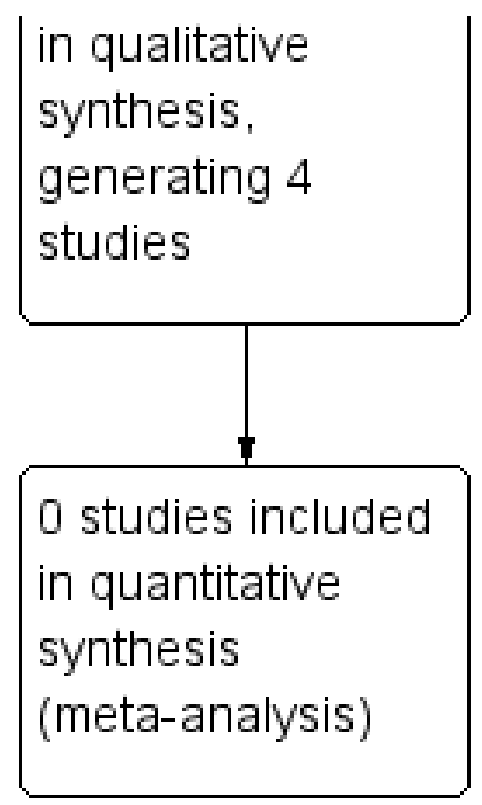

\section{Included studies}

Eleven studies were included in this review ( $\mathrm{n}=778$ ), 10 in children (Bergqvist 2005; El-Rashidy 2013; Kim 2016; Kossoff 2007; Lambrechts 2017; Neal 2008; Raju 2011; Seo 2007; Sharma 2013; Sharma 2016) and 1 in adults (Zare 2017). These studies were conducted across various healthcare systems worldwide. Six studies compared a KD to a control group (El-Rashidy 2013; Lambrechts 2017; Neal 2008; Sharma 2013; Sharma 2016; Zare 2017) and 5 studies compared one KD intervention to another type of KD intervention (Bergqvist 2005; Kim 2016; Kossoff 2007; Raju 2011; Seo 2007). A summary of studies included can also be found in the Characteristics of included studies tables.

\section{Bergqvist 2005 (USA)}

Bergqvist 2005 was a prospective, randomised, single-centre study of 48 participants aged one to 14 years (mean 5.3, standard deviation (SD) 2.7) comparing fasting and gradual-onset ketogenic diets (KDs) (4:1) over a three-month period. Participants were recruited from The Children's Hospital of Philadelphia and randomised into two groups of equal numbers using permuted blocks of random size. Participants were stratified by age, one to two years and two to 14 years to aid equal allocation. Baseline data of seizure activity was collected 28 days prior to diet initiation. There was no significant difference in participant demographics between the groups. Inclusion criteria applied were: children aged one to 14 years, having one or more seizures per 28 days, tried at least three antiepileptic medications and a discontinuation of steroidal medication three months previous. Exclusion criteria applied to children with metabolic disorders, genetic disorders and known or suspected neurodegenerative disorders. Forty-two per cent of children included in the study had cerebral palsy. The study aimed to compare the efficacy of fasting KD to gradual initiation KD. This study assessed seizure reduction, ketosis and adverse effects.

This study was supported in part by RRK-23 16074 and General Clinical Research Center (MO1RR00240), the Nutrition Center of the Children's Hospital of Philadelphia, P30 HD26979, and the Catharine Brown Foundation.

\section{El-Rashidy 2013 (Egypt)}

El-Rashidy 2013 was a single-centre RCT of 40 participants aged 12 to 36 months (mean 27.13, SD 6.63) to compare two different dietary interventions and a control group (polytherapy). Participants were recruited from the Paediatric Neurology Outpatient Clinic at Children's Hospital Ain Shams University and were randomised into one of three groups; modified Atkins diet (MAD) (macronutrients represented as a percentage of total daily energy $-10 \%$ carbohydrate, $60 \%$ fat, $30 \%$ protein) (15 children), classic ketogenic liquid diet (4:1) (10 children) and a control (polytherapy) (15 children). There was no significant difference in age or gender across the groups. The trial excluded children under the age of one year diagnosed with idiopathic epilepsy or with other systemic chronic conditions. Two children in the classic group had infantile spasms and one child in the classic group had myoclonic encephalopathy. Aims of the study were to assess efficacy and tolerability. This study reported reduction in seizure frequency at three and six months, adverse effects and attrition rates.

No external funding support was received for this study beyond the treating hospital (Children's hospital, Faculty of Medicine, Ain Shams University).

\section{Kim 2016 (Korea)}

Kim 2016 was a prospective, randomised, single-centre trial of participants aged 1 to 18 years with drug-resistant epilepsy, comparing MAD (10 g carbohydrate per day for first month followed by increase to maximum of $10 \%$ total energy requirements, with additional calorie restriction to $75 \%$ recommended daily intake) and classic KD (4:1 ratio). Participants were randomised using stratified permuted block randomisation and a minimisation method was used to stratify patients by age to aid equal allocation; one to two years, two to six years and six to 18 years. Baseline activity of seizure data was collected for four weeks prior to diet 
initiation. One hundred and four participants were recruited, 53 received a MAD and 51 received a KD for a period of six months. All recruited participants were hospitalised to commence the diet and followed a non-fasted initiation protocol. No significant difference was observed in baseline demographics between the groups. Epilepsy syndromes included Lennox-Gastaut syndrome (10 participants in the MAD and 8 participants in the KD group), West syndrome (8 participants in the MAD and 12 participants in the KD group), myoclonic astatic epilepsy (1 participant in each group) and Dravet syndrome (2 participants in the MAD and 4 participants in the KD group). Other inclusion criteria applied were: aged one to 18 years, more than four seizures per month, and treatment failure of two or more antiepileptic drugs (AEDs). Exclusion criteria included history of previous dietary therapy, hyperlipidaemia, renal calculi, or any other medical conditions incompatible with dietary therapy. The study aimed to compare the efficacy, safety and tolerability of the classic KD and MAD. This study reported on seizure reduction and seizure freedom, attrition and adverse effects.

This study was supported financially by the National Research Foundation of Korea (NRF) funded by the Ministry of Education, Science and Technology.

\section{Kossoff 2007 (USA)}

Kossoff 2007 was a prospective, randomised, cross-over controlled trial of 20 participants aged three to 18 years comparing daily carbohydrate limits of $10 \mathrm{~g}$ and $20 \mathrm{~g}$, using the MAD. Participants were recruited from the John Hopkins Hospital outpatient paediatric epilepsy clinic and randomised into two groups: 10 g carbohydrate MAD (10 children) or $20 \mathrm{~g}$ carbohydrate MAD (10 children), and followed for a three-month period. After this time, participants were crossed over into the other group and followed for a further three months. A return to the previous carbohydrate amount was permitted after two weeks if parents deemed seizure control to be worse. There was no significant difference in participant demographics between the groups. Inclusion criteria were: aged three to 18 years, prior use of at least two anticonvulsants and daily seizures. Epilepsy syndromes included were idiopathic (15 children), Rett syndrome (2 children), cortical dysplasia ( 2 children) and tuberous sclerosis complex (1 child). Exclusion criteria included children with prior experience of the diet for more than seven days, hypercholesterolaemia, kidney dysfunction, body mass index less than $3 \%$ for age and children with heart disease. The study aimed to investigate the ideal starting value of carbohydrate in the MAD. This study reported seizure reduction, level of ketosis and tolerability.

Funding support for this study was not stated.

\section{Lambrechts 2017 (the Netherlands)}

Lambrechts 2017 was a prospective, randomised, single-centre, controlled trial of participants aged one to 18 years, with drugresistant epilepsy, comparing KD (classic KD and medium-chain triglyceride (MCT) KD combined, ratio of fat to carbohydrate and MCT amount not specified) to a control (care as usual) over a four-month period. Follow-on studies then compared long-term clinical outcomes at 16 months, cognitive and behavioural impacts and an economical evaluation. Participants were recruited from a tertiary referral centre for epilepsy in the Netherlands and randomised into two groups using computer software, based on the minimisation method, after a one-month baseline period. Fiftyseven participants were recruited; 29 received KD and the 28 controls received care as usual. Patients randomised to control (care as usual) were treated with KD after an initial delay of four months. KD was commenced during a five-day hospitalisation. Differences were noted in baseline demographics between groups for gender (18 male in KD group and 9 male in control group), daily seizures ( 10 participants in KD group and 3 participants in control group), almost daily seizures (5 participants in KD group and 10 participants in control group) and etiology (9 genetic aetiology in $\mathrm{KD}$ group and 1 in control group; 2 structural aetiology in KD group and 10 structural in control group). Epilepsy syndromes included West syndrome ( 3 participants in KD group and 2 participants in control), Lennox-Gastaut syndrome (1 participant in KD group), Doose syndrome (3 participants in KD group and 2 participants in control), Dravet syndrome (1 participant in KD group), childhood absence epilepsy (1 participant in KD group), epilepsy with myoclonic absences (1 participant in KD group), generalised epilepsies (4 participants in KD group and 6 participants in control) and localisation-related epilepsies (12 participants in each group). Other inclusion criteria included: aged between one and 18 years, seizures not adequately controlled by two or more AEDs and surgical remediable causes of epilepsy not viable. Exclusion criteria included: medical contraindications or behavioural or motivational problems that would prelude compliance. The study assessed seizure reduction, adverse events, attrition, quality of life, costeffectiveness, cognitive and behavioural change.

The study was supported financially by the Netherlands Organisation for Health Research and Development.

\section{Neal 2008 (UK)}

Neal 2008 was a prospective, randomised, non-blinded, controlled trial of 145 participants aged two to 16 years comparing KD (classic and MCT combined) to controls over a three-month period, with a follow-on study that compared classic KD (4:1) versus MCT $\mathrm{KD}$ (macronutrients as approximate percentage of total energy requirements; $15 \%$ carbohydrate, $10 \%$ protein, $30 \%$ long-chain fatty acids, $45 \%$ medium-chain triglycerides) over a 12-month period. Most participants were recruited from Great Ormond Street Hospital for Children, with a few participants seen in Central Middlesex Hospital and a residential centre (National Centre for Young People with Epilepsy). Participants were randomised, using a computer package, to commence a diet (classic or MCT) after a four-week baseline or after baseline and a further three months of seizure recording, with the latter group acting as the control. The study used three defined age groups to aid the randomisation between groups ( 2 to 6 years, 7 to 11 years and 12 to 16 years). Participant demographics were well matched between the groups. Inclusion criteria were: children aged two to 16 years, with daily seizures and more than seven seizures per week, who had not responded to two or more AEDs who had not previously been treated with a KD. Exclusion criteria included: hyperlipidaemia, renal stones or organic acid deficiency syndromes. Fourteen participants had Lennox-Gastaut syndrome and 11 had West syndrome. The study aimed to investigate the efficacy of the KD in comparison to a control and to compare classic KD versus MCT KD for efficacy and tolerability at three, six and 12 months. This study reported the reduction in seizure frequency and tolerability (assessed via a questionnaire at 3, 6 and 12 months).

This study received financial support from HSA, Smiths Charity, Scientific Hospital Supplies, and the Milk Development Council. University College London Institute of Child Health received 
funding as a National Institute for Health and Research Specialist Biomedical Research Centre.

\section{Raju 2011 (India)}

Raju 2011 was a randomised, non-blinded, open-label, parallel controlled trial of children aged six months to five years, with drugresistant epilepsy comparing a 4:1 and a 2.5:1 ratio KD. Participants were recruited from a single-centre, paediatric department of a tertiary care hospital in India. Participants were randomised using a computer-generated random number table and concealment was undertaken using opaque envelopes. Thirty-eight participants were recruited, 19 received a 4:1 ratio KD and 19 received a 2.5:1 KD, with outcomes being assessed three months after dietary initiation. There were no significant differences between participant demographics at baseline. Epilepsy syndromes included were West syndrome (9 participants in 4:1 KD group and 7 participants in 2.5:1 KD group), Lennox-Gastaut syndrome (8 participants in 4:1 KD group and 9 participants in 2.5:1 KD group), Doose (no participants in 4:1 KD group and 2 participants in 2.5:1 KD group) and unclassified syndromes (2 participants in 4:1 KD group and 1 participant in 2.5:1 KD group). The trial included participants with cerebral palsy ( 15 participants in 4:1 KD group and 9 participants in 2.5:1 KD group). The inclusion criteria were: children aged six months to five years, at least two seizures per month, despite appropriate use of at least two AEDs and at least one newer AED. The exclusion criteria were: known or suspected inborn errors of metabolism, systemic illness or surgical remediable causes of epilepsy. The aims of the study were to compare the efficacy and tolerability of 2.5:1 KD versus 4:1 KD. This study assessed the proportion of participants with more than $50 \%$ reduction in seizure frequency in both groups and adverse effects.

No funding was received for this study.

\section{Sharma 2013 (India)}

Sharma 2013 was an open-label, single-centre, parallel-group, RCT of children aged two to 14 years with drug-resistant epilepsy comparing the MAD (10 g carbohydrate per day) to a control group. This was conducted in a single, tertiary care centre. Authors noted the study design to be similar to that of Neal 2008. Participants were randomised into an intervention (MAD) or a control (care as usual) arm using computer-generated random number tables. Concealment was carried out using opaque sealed envelopes. There were 102 participants, 50 received MAD and 52 received a normal diet for a period of three months. There were no significant differences in participant demographics across the two groups. Epilepsy syndromes included Lennox-Gastaut syndrome (25 participants in the MAD group and 22 participants in control group), West syndrome (9 participants in the MAD group and 10 participants in control group) and myoclonic astatic epilepsy (2 participants in the MAD group and 3 participants in control group). Other inclusion criteria were: two to 14 daily seizures and previously tried three AEDs. Exclusion criteria were: known or suspected inborn errors of metabolism, systemic illness or motivational issues of the family that would prelude compliance. Seizure frequency was recorded for a four-week baseline period and repeated at the end of the three-month study period. The aim of the study was to evaluate the efficacy of the MAD. Outcomes reported were seizure frequency, tolerability and adverse effects.

The lead author (Sharma) was financially supported as a Senior Research Associate in the "Scientists pool scheme" of the Council for Scientific and Industrial Research (CSIR), Government. of India, for this study.

\section{Sharma 2016 (India)}

Sharma 2016 was a prospective, randomised, non-blinded, control trial of participants aged two to 14 years, with drug-resistant epilepsy to compare a simplified MAD (SMAD, $10 \mathrm{~g}$ carbohydrate per day) to a control (care as usual). This study was conducted in a single, tertiary care centre. Authors note the study design to be similar to that of Neal 2008 and Sharma 2013 . Participants were randomised into the intervention (SMAD) or control arm using computer-generated randomisation sequencing, of variable block sizes (2, 4 or 6$)$. Concealment was carried out through the use of opaque sealed envelopes. Eighty-one participants were recruited; 41 were randomised to the SMAD group and 40 to the control group, and followed up for a three-month period. No significant differences were seen in participant demographics across the two groups. Epilepsy syndromes included West syndrome (22 participants in SMAD and 25 participants in the normal diet group) and Lennox-Gastaut syndrome (14 participants in SMAD and 13 participants in control group). Inclusion criteria were applied: children aged two to 14 years, daily seizures (or more than 7 seizures per week) despite at least two AEDs and diet therapy naive. Exclusion criteria applied included: known or suspected inborn errors of metabolism, systemic illness, surgically remediable causes of epilepsy or motivational issues in the family that would preclude compliance. The study aimed to develop and evaluate a simple, easy to understand variation of the MAD. Outcomes reported were seizure reduction, tolerability, adverse events and non-seizure domains.

This study was supported by the Indian Council of Medical Research (ICMR).

\section{Seo 2007 (Korea)}

Seo 2007 was a single-centre RCT of 76 children with intractable childhood epilepsy aged four months to 16 years comparing 3:1 KD and 4:1 KD. Participants were recruited from a paediatric epilepsy clinic in Severance Children's Hospital and were randomised into two groups: 4:1 KD group (40 participants) and 3:1 KD group (36 participants) and the diet was followed for three months. A baseline seizure frequency monitoring period was completed two months prior to commencement of KD. After a three-month period of the diet, children who were seizure free in the $4: 1$ group were recommended to change to a 3:1 ratio, and children who were not seizure free in the 3:1 group were recommended to change to a 4:1 ratio and re-evaluated after a further three months. There were no significant differences in participant demographics between the groups. Epilepsy syndromes included Lennox-Gastaut syndrome and the study also included participants with infantile spasm. The inclusion criteria were: more than four seizures per month and seizures were not controlled by at least three AEDs. The exclusion criteria were: children with metabolic disorders or known or suspected neurological degenerative disorders (or both). The study aimed to compare the antiepileptic efficacy and diet tolerability of 3:1 and 4:1 KDs. This study assessed a reduction in seizure activity from baseline and tolerability.

This study was financially supported by Yonsei University Research Fund of 2003. 


\section{Zare 2017 (Iran)}

Zare 2017 was a prospective, RCT of participants aged 18 to 57 years, with drug-resistant epilepsy, comparing MAD (15 g carbohydrate; total energy derived from $4 \%$ to $6 \%$ carbohydrate, $20 \%$ to $30 \%$ protein, $60 \%$ to $70 \%$ fat) to a control (care as usual) over a 2 month period. This study was conducted in a single-centre, and recruited participants referred between February 2010 and December 2012. Participants were randomised to the intervention arm (MAD) or the control arm using a random number table. Concelment of allocation was not stated. Sixty-six participants were recruited, 34 were randomised to the MAD group and 32 to the control group, and followed for a two-month period. No significant differences were noted in baseline characteristics across the groups. The inclusion criteria applied were: adults aged 18 to 57 years, with drug-resistant epilepsy (2 or more seizures per month) despite two or more AEDs. The exclusion criteria included: prior use of Atkins or MAD for greater than one week, use of KDs in the last year, kidney disease, heart disease, renal disease, hypercholesterolaemia, coronary heart disease, cerebral vascular disease, atherosclerosis, previous myocardial infarctions, renal dysfunction, pregnancy, body mass index (BMI) $<18.5 \mathrm{~kg} / \mathrm{m}^{2}$, status epilepticus within the past six months or a two-week seizure-free period in the last six months. The study aimed to assess the efficacy of MAD in adults with drug-resistant epilepsy. This study assessed seizure reduction and adverse events.
The study was supported by the Plastic Surgery Research Centre, Isfahan University of Medical Sciences, Isfahan.

\section{Excluded studies}

The present update excluded three studies at full-text review. One study solely included infantile spasms (Dressler 2015), one study was abstract only with no further data (Singh 2015), and one study was successfully blinded after fasting (by administration of saccharin or glucose) (Freeman 2009); however, the Freeman 2009 trial lasted for only 12 days and ketosis was not completely eliminated in the glucose arm. A summary can be found in Characteristics of excluded studies table.

The previous edition of this review excluded four studies. Three were not RCTs (Freeman 1999; Hemingway 2001; Smith 2011) and one study was successfully blinded after fasting (by administration of glucose or saccharin), however was only for twelve days and ketosis was not completely eliminated in the glucose arm (Freeman 2009).

\section{Risk of bias in included studies}

There were 11 RCTs that generated 15 publications reviewing the use of ketogenic diets, all of which were appropriate for analysis of bias. For further details please refer to Characteristics of included studies table and Figure 2; Figure 3.

\section{Figure 2. Risk of bias graph: review authors' judgements about each risk of bias item presented as percentages} across all included studies.

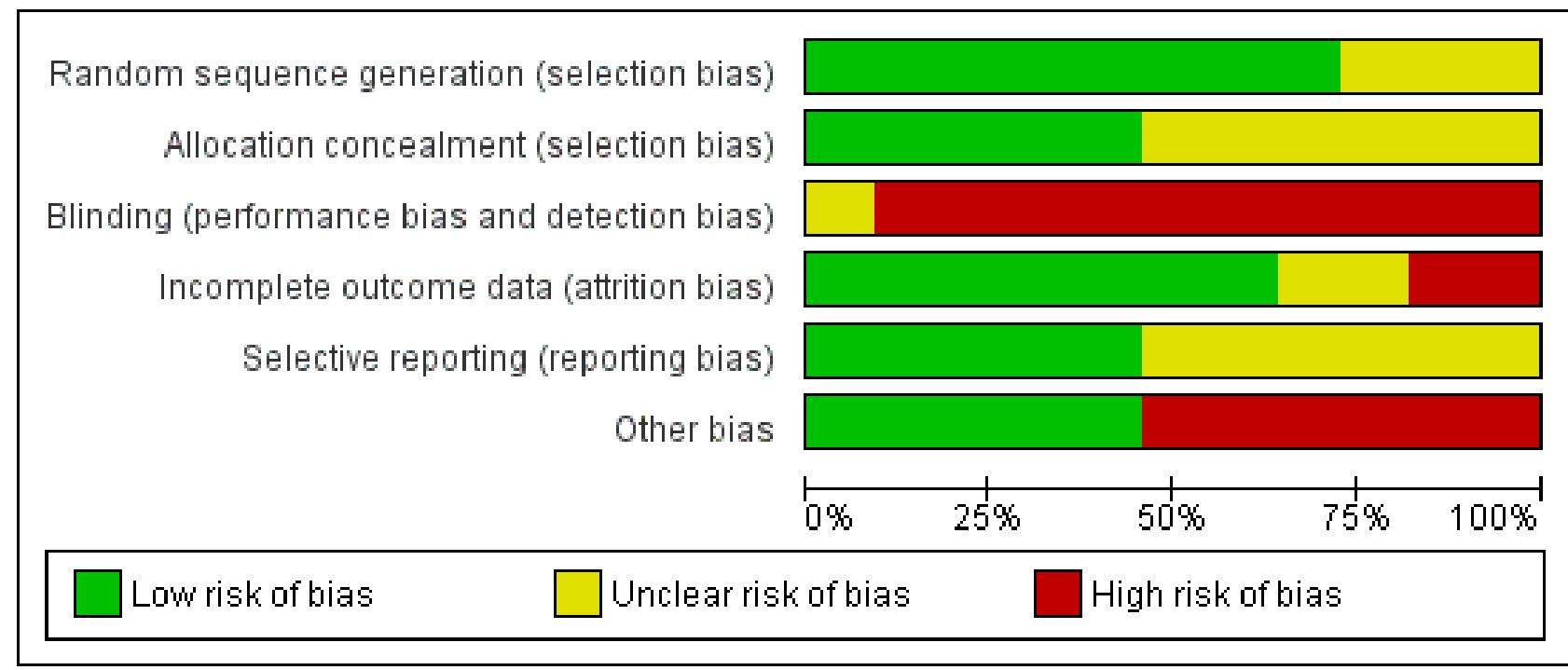


Figure 3. Risk of bias summary: review authors' judgements about each risk of bias item for each included study.

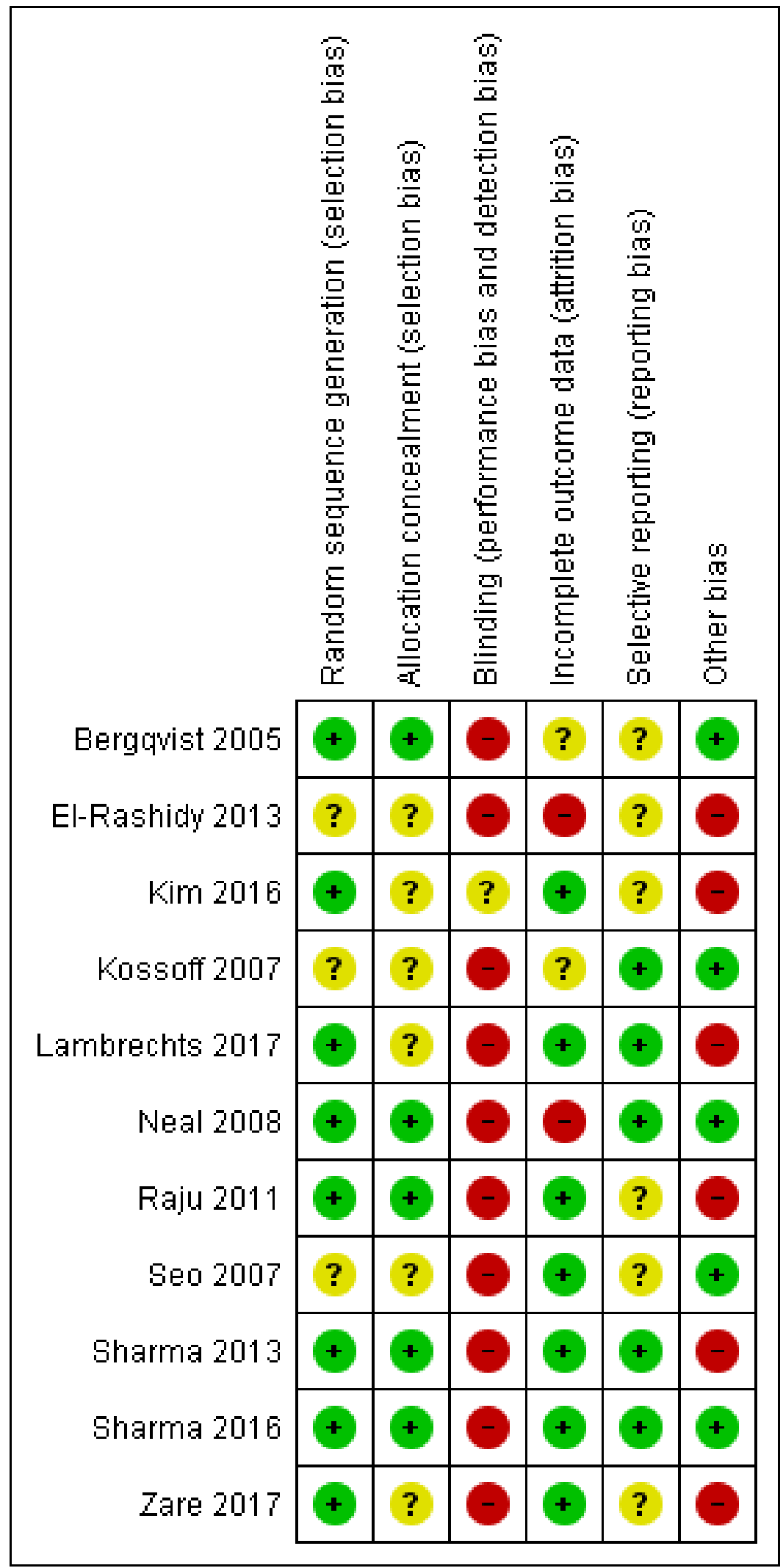




\section{Allocation}

Four studies used a computer-generated method of sequence generation and allocation concealment (Kim 2016; Neal 2008; Raju 2011; Sharma 2013), one study used a permuted block randomisation method (Bergqvist 2005), and one study used a permuted block randomisation method with opaque sealed envelope concealment (Sharma 2016). We rated these studies at low risk of allocation bias.

The method of sequence generation and allocation concealment was unclear in three studies (El-Rashidy 2013; Kossoff 2007; Seo 2007), whilst allocation concealment alone was unclear in three studies (Bergqvist 2005; Lambrechts 2017; Zare 2017).

\section{Blinding}

We rated 10 studies at high risk of performance bias and detection bias (Bergqvist 2005; El-Rashidy 2013; Kossoff 2007; Lambrechts 2017; Neal 2008; Raju 2011; Seo 2007; Sharma 2013; Sharma 2016; Zare 2017). This may be due to the design of such studies, in that blinding participants and study personnel did not occur. One study blinded study personnel, but it is unclear if outcome assessors were blinded and participants were not blinded, therefore we rated this study as unclear in terms of blinding (Kim 2016).

\section{Incomplete outcome data}

Two studies reported comparable dropout rates across the groups but did not complete an intention-to-treat (ITT) analysis (Bergqvist 2005; Kossoff 2007). One study reported comparable dropout rates across the groups but it is unclear if an ITT analysis was competed (Kim 2016). These two studies had an unclear attrition bias. Five studies also reported comparable dropout rates across the groups and completed an ITT analysis (Lambrechts 2017; Raju 2011; Seo 2007; Sharma 2013; Sharma 2016). Two studies reported greater dropout in one group, but carried out an ITT analysis (Neal 2008; Zare 2017). We rated these seven studies at low risk of attrition bias.

One study reported uneven dropout rates across the groups and did not complete an ITT analysis (El-Rashidy 2013). We rated this study at high risk of attrition bias.

\section{Selective reporting}

One study protocol has been published and was available for review (Lambrechts 2017). We contacted the remaining authors of all included studies to request protocols. Three study authors provided the protocol for the included studies (Kossoff 2007; Neal 2008; Sharma 2016). On reviewing the outcomes, there was no evidence to suggest selective reporting for any of these four studies. Therefore, we rated these studies at low risk of bias. Protocols for the remaining seven studies were unavailable and we rated these studies at unclear risk of selection bias (Bergqvist 2005; El-Rashidy 2013; Kim 2016; Raju 2011; Seo 2007; Sharma 2013; Zare 2017).

\section{Other potential sources of bias}

One study reported three participants in one intervention group to have other conditions; two had been diagnosed with infantile spasms and one with myoclonic encephalopathy (El-Rashidy 2013).

A high level of comorbidity among all groups was reported in one study, and although the groups were comparable within this study, bias may be introduced when evaluating in a meta-analysis (Raju 2011).
One study excluded children where motivational issues within the family had been identified, due to possible impacts upon compliance rates (Sharma 2013).

An energy restriction of $75 \%$ of recommended daily intake was introduced to the MAD group and not to the classical KD group in another study (Kim 2016). This could potentially enhance ketosis in the MAD group to the disadvantage of the classical KD group. In the same study, the significant difference noted in seizure reduction in the under-two's in favour of the classical KD, was likely to be underpowered due to sub analysis.

One study contributed several potential sources of bias (Lambrechts 2017). Participants with severe motivational and behavioural difficulties were excluded, despite the study assessing the effects of KD on these outcomes. Differences were noted in baseline mood and behaviour scores, gender balance and baseline seizure frequency, however significance values were not presented by the authors to fully assess this. The study was under powered to assess quality of life; quality-adjusted life years (QALYs) were assessed at four months which may be too premature to assess changes in quality of life, and at the start of the study no suitable quality of life instrument was available for utility measures in children aged 0 to 18 years, resulting in some extrapolation from adult tariffs. As the control group received KD after four months, control data were extrapolated from four months to sixteen months outcomes; although this may have been due to ethical rationale. The KD group also report significantly greater gastrointestinal side effects at baseline compared to the control group $(P<0.05)$, which could negatively impact the dietary intervention.

One study reported numerical errors within the text of the article in comparison to the tables and did not report a power calculation (Zare 2017). Low levels of urinary ketosis were reported (1.75+/$0.28 \mathrm{mmol} / \mathrm{L}$ ) which could affect seizure outcomes.

We rated these studies at high risk of bias.

A subjective, non-validated tool was used to assess alertness, speech, sleeping, social and behavioural changes in one study. However, as these measures were assessed using non-validated tools they were not included in this review and had low impact upon bias (Sharma 2016).

There were no other sources of bias identified in four studies (Bergqvist 2005; Kossoff 2007; Neal 2008; Seo 2007).

\section{Effects of interventions}

See: Summary of findings for the main comparison Summary of Findings - Ketogenic diets compared to control for people with epilepsy; Summary of findings 2 Summary of findings - Ketogenic diets compared with other ketogenic diets for people with epilepsy

All outcomes are presented in Summary of findings for the main comparison and Summary of findings 2 and are described in more detail below.

\section{Seizure freedom ( $100 \%$ reduction in seizure frequency)}

Nine studies $(n=636)$ reported on seizure freedom.

Four studies $(n=350)$ reported results for a KD intervention compared to a control group. 
- Neal 2008 reported one participant out of $73(1 \%)$ to be seizure free after three months of following a KD (classic and MCT).

- Lambrechts 2017 reported $12 \%$ (3/26) of participants in the KD group to be seizure free at four months, compared to $9 \%(2 / 22)$ of the control group. These values remain unchanged when reported at 16 months.

- Following a SMAD, Sharma 2016 reported 15\% (6/41) of participants became seizure free, compared to $5 \%(2 / 40)$ in the control; this result was not significant $(P=0.26)$

- Zare 2017 reported 0\% seizure freedom in both the MAD and the control group.

Five studies ( $n=286)$ compared different KD interventions.

- Raju 2011 reported 26\% (5/19) of participants following a 4:1 KD and $21 \%(4 / 19)$ of participants following a 2.5:1 KD to be seizure free at three months.

- Seo 2007 found a greater response rate to both ratios of the KD, reporting $55 \%(22 / 40)$ of participants to be seizure free after following a 4:1 KD for three months compared to $35 \%$ (11/36) of participants following a 3:1 KD.

- When comparing a fasting-onset and a gradual-onset KD, Bergqvist 2005 stated 21\% (5/24) of participants of both fastingonset and gradual-onset KD groups were seizure free at three months.

- When investigating the effects of MAD on seizure freedom, Kim 2016 reported a significant difference between classic KD (33\%; $17 / 51$ participants) and MAD (25\%; $13 / 53$ participants) after three months $(P=0.374)$, but no difference after six months. When results were divided into subsequent age categories ( 1 to 2 years, 2 to $<6$ years and 6 to 18 years) more children under the age of two years experienced seizure freedom following the classic KD (9/17) compared to the MAD (4/20) $(P=0.047)$. However, this result is likely to be statistically underpowered.

- Kossoff 2007 reported 10\% (2/20) of participants to be seizure free by six months. However, the intervention group (10 g or 20 g carbohydrate per day via MAD) was not stated.

\section{Seizure reduction $\mathbf{5 0 \%}$ or greater reduction in seizure frequency)}

All 11 studies $(n=778)$ reported on seizure reduction.

Five studies $(n=452)$ compared KD intervention to a control group.

- Neal 2008 reported $38 \%$ (28/73) of participants had greater than $50 \%$ seizure reduction after three months in the KD (classic and $\mathrm{MCT}$ ) group compared to $6 \%$ (4/72) of participants in the control group $(\mathrm{P}<0.0001)$.

- Lambrechts 2017 stated 39\% (10/26) in the KD group compared to $9 \%(2 / 22)$ in the control group experienced greater than $50 \%$ seizure reduction at four months. After 16 months, seizure reduction (of greater than 50\%) had reduced from $39 \%$ to $27 \%(6 / 22)$ in the KD group and $9 \%(2 / 22)$ of the control group. Lambrechts 2017 presented significance values as overall responders (seizure reduction and seizure freedom combined). For the KD group $50 \%(13 / 26)$ of participants responded to $\mathrm{KD}$ and $18 \%(4 / 22)$ in the control group, illustrating significant response at four months for the $K D$ group compared to the control $(P<0.05)$. When comparing MAD to a control group,
- Sharma 2013 reported significantly higher results in the MAD group (52\%) to the control ( $11.5 \%, \mathrm{P}=0.001)$, when comparing greater than $50 \%$ seizure reduction at three months.

- Using a SMAD, Sharma 2016 later supported these results, reporting $56 \%(23 / 41)$ of participants in the sMAD group experienced greater than $50 \%$ seizure reduction compared with $8 \%(3 / 40)$ in the control group $(\mathrm{P}<0.0001)$.

- Zare 2017 reported 35\% (12/34) in the MAD group and $0 \%(0 / 32)$ in the control group had greater than $50 \%$ reduction in seizures at two months $(P=0.001)$.

Six studies $(n=326)$ compared different KD interventions.

- Raju 2011 found the number of participants with greater than $50 \%$ seizure reduction after three months to be $58 \%(11 / 19)$ in the $4: 1 \mathrm{KD}$ group and $63 \%(12 / 19)$ in the $2.5: 1 \mathrm{KD}$ group; however, there was no significant difference.

- Seo 2007 stated 85\% (34/40) of participants following a 4:1 KD and $72.2 \%(26 / 36)$ of participants following a 3:1 KD to have greater than $50 \%$ seizure reduction after three months. Seo 2007 reported that antiepileptic efficacy was significantly greater in the 4:1 KD group than the 3:1 KD group $(P=0.041)$, but it was unclear as to whether this referred to seizure reduction, seizure freedom or both.

- When comparing fasting-onset and gradual-onset KD, Bergqvist 2005 found $58 \%(14 / 24)$ of participants in the fasting-onset KD and $67 \%(16 / 24)$ of participants in the gradual-onset KD group to have greater than $50 \%$ seizure reduction at three months.

- When comparing classic KD to MAD, Kim 2016 reported $43 \%$ $(22 / 51)$ of participants in the classic KD and $42 \%(22 / 53)$ in the MAD group $(P=0.527)$ reporting greater than $50 \%$ seizure reduction. At six months 39\% (20/51) of participants in the classic KD group and $36 \%$ of the MAD group reported greater than $50 \%$ seizure reduction $(P=0.321)$, therefore no difference was observed between the groups.

- When comparing proportions of carbohydrate in the MAD group, Kossoff 2007 reported a significant difference $(P=0.03)$ in seizure reduction after three months, between $10 \mathrm{~g}$ carbohydrate MAD and $20 \mathrm{~g}$ carbohydrate MAD, with $60 \%(6 / 10)$ of participants in the $10 \mathrm{~g}$ carbohydrate/day group having greater than $50 \%$ seizure reduction compared to $10 \%(1 / 10)$ of participants in the 20 g carbohydrate/day group.

\section{Adverse effects}

All studies ( $\mathrm{n}=778$ ) reported adverse effects of the dietary interventions.

For those studies investigating the classical KD, the main adverse effects were gastrointestinal symptoms, including vomiting, constipation and diarrhoea (Bergqvist 2005; El-Rashidy 2013; Kim 2016; Lambrechts 2017; Neal 2008; Raju 2011; Seo 2007). Weight loss was also reported on in three KD studies (Bergqvist 2005; Lambrechts 2017; Raju 2011).

Seo 2007 found gastrointestinal symptoms to be significantly worse in the 4:1 ratio compared with the $3: 1$ ratio $K D(P=0.038)$, while Neal 2008 reported vomiting to significantly affect more participants in the classical KD (45\%) compared with the MCT KD group (13\%, P $<0.05)$. Raju 2011 found weight loss to affect more participants $(3 / 19)$ in the 4:1 ratio $K D$ group than in the 2.5:1 (1/19) ratio KD group. Bergqvist 2005 found gradual-onset KD participants lost 
significantly less weight than the fasting-onset KD group; -0.95 $\mathrm{kg}(95 \%$ confidence interval $(\mathrm{Cl})-2.9$ to 0.6$)$ with fasting-onset $\mathrm{KD}$ compared to $-0.3 \mathrm{~kg}(95 \% \mathrm{Cl}-2.1$ to 1.5$)$ with gradual-onset $\mathrm{KD}$ ( $\mathrm{P}$ $=0.006)$. Lambrechts 2017 reported a clinically relevant reduction in weight in one participant and in height in one other. Neal 2008 also reported statistical significance with regards to a lack of energy at three months, affecting $36 \%$ of participants in the classical KD group compared to $14 \%$ of participants in the MCT group $(P<$ 0.05). The only statistically significant difference between the MAD and classic KD groups reported by Kim was hypercalciuria at three months, affecting $43 \%(22 / 39)$ of the classic KD group and $23 \%$ $(12 / 47)$ of the MAD group $(P=0.004)$.

Other adverse effects reported by the studies investigating the classical KD in lower numbers were respiratory tract infection, infectious disease (pneumonia and sepsis), acute pancreatitis, decreased bone matrix density, gallstones, renal stones, fatty liver, nephrocalcinosis, hypercholesterolaemia, status epilepticus, acidosis, dehydration, tachycardia, extended hospital stay, hunger and abdominal pain.

Adverse effects were also reported in the MAD studies (El-Rashidy 2013; Kossoff 2007; Sharma 2013; Sharma 2016; Zare 2017).

Four studies reported constipation to affect the dietary intervention groups, with $20 \%$ to $46 \%$ of participants affected. ElRashidy 2013 reported constipation to affect $15.4 \%$ of participants in the MAD group and $25 \%$ of participants in the classic group, but no significance was reported. Sharma 2013 and El-Rashidy 2013 reported vomiting to affect $10 \%$ of participants in the MAD group and 30\% of participants in the classic group. El-Rashidy 2013 also reported diarrhoea to affect more of the MAD participants than the classic KD participants (15.4\% in the MAD group, $12.5 \%$ in the classic group). Kossoff 2007 found no significant difference between median weight change in the $10 \mathrm{~g}$ and $20 \mathrm{~g}$ carbohydrate MAD groups in the first three months $(P=0.44)$. Sharma 2016 found the number of participants reporting symptoms of constipation, diarrhoea, lethargy and anorexia reduced over three months in the SMAD group. Weight loss was the only exception which increased over time, affecting 14\% (5/36) participants by three months. Zare 2017 reported a significant reduction in BMI over two months in the MAD group $\left(23.07 \pm 3.6 \mathrm{~kg} / \mathrm{m}^{2}\right.$ to $\left.22.32 \pm 3.52 \mathrm{~kg} / \mathrm{m}^{2} ; \mathrm{P}=0.038\right)$. Zare 2017 also reported significantly more participants in the MAD group experienced an increase in cholesterol compared to the control (7/34 versus 0/32; $P=0.004)$. An increased liver enzyme was experienced by both the MAD $(14.7 \% ; 5 / 34)$ and the control group $(15.6 \% ; 7 / 32)(P=0.007)$. Other adverse effects were anorexia, lethargy, lower respiratory tract infections and hyperammonaemic encephalopathy.

\section{Cognitive and behaviour outcomes}

Lambrechts 2017 was the only study to investigate the effect of KDs upon cognition and behaviour, reporting participants in the KD group to be more active $(P=0.005)$, more productive $(P=0.039)$ and less anxious $(P=0.049)$ after four months, compared to the control group.

\section{Quality of life}

Lambrechts 2017 was the only study to investigate the effect of KDs on quality of life, reporting no significant difference in QALYs between the KD group and control group at four or 16 months ( $P$ value not reported).

\section{Attrition rate}

All studies $(n=778)$ experienced dropouts.

In the studies investigating classic KD, dropouts ranged from $10 \%$ to $26 \%$ at three or four months (Bergqvist 2005; El-Rashidy 2013; Neal 2008; Raju 2011; Seo 2007), up to 33\% by six months (Kim 2016), and $42 \%$ at 16 months (Lambrechts 2017). Reasons for dropout included lack of efficacy, intolerance, adverse effects, refusal to eat, non-acceptance of diet by other family members, along with medical conditions including acute pancreatitis, viral gastrointestinal illness, change in seizure pattern, withdrawal of consent, compliance, respiratory distress and increased seizure activity.

In the studies investigating the MAD, dropout rates were between 7\% and 50\% (El-Rashidy 2013; Kossoff 2007; Sharma 2013; Sharma 2016; Zare 2017). Reasons for dropout reported by El-Rashidy 2013 and Sharma 2013 were non-acceptance of the diet, refusal to eat, anorexia with lethargy, lost to follow-up and weight loss; along with medical conditions, including lower respiratory tract infections and hyperammonaemic encephalopathy. Kossoff 2007 did not report reasons for dropouts; however, they found no significant difference between $10 \mathrm{~g}$ and $20 \mathrm{~g}$ carbohydrate in MAD dropout rates $(P=0.33)$.

\section{DISCUSSION}

\section{Summary of main results}

The present update identified four additional randomised controlled trials (RCTs) and, therefore, this review includes 11 RCTs. All of the studies assessed the efficacy of various dietary interventions for children with epilepsy, with the exception of Zare 2017 who assessed the efficacy of the modified Atkins diet (MAD) for adults with epilepsy.

The review presented some promising, although limited, evidence for the use of ketogenic diets (KDs) in epilepsy. Reported rates of seizure freedom reached $55 \%$ in a $4: 1 \mathrm{KD}$ group after three months and reported rates of seizure reduction reached $85 \%$ in a $4: 1 \mathrm{KD}$ group after three months (Seo 2007).

Interestingly, Bergqvist 2005 found no significant difference between the fasting-onset and gradual-onset KD for rates of seizure freedom and reported a greater rate of seizure reduction in the gradual-onset KD group.

Studies assessing the efficacy of the MAD in children reported seizure freedom rates of up to $25 \%$ and seizure reduction rates of up to $60 \%$. One study reported a significant difference between classic KD and MAD after 3 months $(P=0.374)$ in terms of seizure reduction, but no difference after six months (Kim 2016). Of further interest, this study is the first RCT to report on KDs in children under two years of age in relation to seizure freedom, suggesting classical KD may be more effective than MAD $(P=0.047)$. However, this result is likely to be statistically underpowered and requires further investigation.

The first RCT for MAD in adults reported seizure reduction rates of $35 \%$ at two months (Zare 2017), which is lower than that of children, but remains statistically significant compared to the control group $(P=0.001)$. 
Adverse effects were fairly consistent across different dietary interventions. The most commonly reported adverse effects were gastrointestinal syndromes. It was common that adverse effects were the reason for participants dropping out of studies. Other reasons for dropout included lack of efficacy, non-compliance and non-acceptance of the diet.

Although there was some evidence for greater antiepileptic efficacy for a 4:1 KD over lower ratios, the 4:1 KD was associated with more adverse effects in the majority of studies.

Only one study assessed the effect of dietary interventions on quality of life and found no difference between quality-adjusted life years (QALYs) when comparing KD to a control (Lambrechts 2017). This study is also the only study to report upon cognitive or behavioural functioning, suggesting the KD group to be more active, more productive and less anxious. However, given the limitations of the study, further evidence investigating the effects of KDs on quality of life and cognitive and behavioural functioning would be beneficial, before drawing conclusions.

\section{Overall completeness and applicability of evidence}

The present review identified only 11 RCTs with a total sample size of 778 people with epilepsy. Due to the clinical and methodological heterogeneity, meta-analysis was not possible for this review. This demonstrates the limitations of the evidence for dietary interventions in people with epilepsy. Furthermore, there is a lack of consensus regarding which dietary intervention is most effective and appropriate, highlighting the need for further research in this area to address these issues.

Only one of the 11 studies reported upon the efficacy of KD in adults. Therefore, further research is required to provide highquality evidence for the use of ketogenic dietary interventions in an adult population, in addition to expanding on evidence in paediatric populations.

\section{Quality of the evidence}

The quality of the evidence was low to very low. This is due to the relatively small sample size and high risk of bias in the included studies. In addition, two of the included studies reported a high incidence of comorbidity (Bergqvist 2005; El-Rashidy 2013).

There was considerable heterogeneity across the included studies in terms of the clinical populations, interventions and methodologies. Therefore, combined data from included studies was problematic and meta-analysis was not possible in this review. This is a limitation of this review and impacts on the quality of evidence presented.

For further details please refer to Summary of findings for the main comparison and Summary of findings 2 .

\section{Potential biases in the review process}

Despite the thorough search strategies, we cannot be certain that we identified and included all relevant data in this review. Should further data be identified following publication of this review, it will be incorporated into subsequent updates.

There was limited information about the included studies, in particular study protocols were unavailable for the majority of included studies, therefore decisions within the risk of bias assessment were often based on insufficient information, resulting in a number of unclear risk of bias judgements.

\section{Agreements and disagreements with other studies or reviews}

We found two prospective studies investigating the effect of KD on epilepsy in an adult population (Kossoff 2008; Moesk 2009). Kossoff 2008 investigated the effects of a MAD (30 participants), while Moesk 2009 used a classic 4:1 KD (9 participants). Dropout rates varied between $30 \%$ and $77 \%$, reportedly due to feelings of hunger, dietary restrictions and lack of efficacy. Moesk 2009 reported that both of the participants who completed the study had greater than $50 \%$ seizure reduction by three months, while Kossoff 2008 reported that $47 \%$ of participants had experienced this level of seizure reduction. Both studies reported an increase in cholesterol levels. The efficacy findings of Kossoff 2008 were similar to those of the included paediatric RCTs discussed above, and slightly greater than the adult RCT (Zare 2017). However, attrition rates experienced by Moesk 2009 were considerably higher than the RCTs conducted on children or the adult RCT by Zare 2017, which may suggest tolerability of a 4:1 KD or lack of efficacy to be problematic in the adult population. We note, however, that the Zare 2017 study was only two months in duration.

Further prospective studies with children reported similar levels of seizure reduction to those of the included RCTs (Coppola 2002; Hosain 2005). Hosain 2005 administered a KD via gastrostomy tubes and reported compliance rates of $100 \%$ (12 children), likely due to the method of delivery.

Retrospective studies found $35 \%$ and $58 \%$ of children to have greater than $50 \%$ seizure reduction following six months of $\mathrm{KD}$ (DiMario 2002; Kang 2005). However, given the time scale, direct comparisons of results are difficult. Adverse effects in both studies were mild and self-limited. Kang 2005 reported a 32\% dropout rate, which is slightly greater than the included RCTs, reportedly due to complications and dietary intolerances. However, four participants were also reported to have died during the study, three due to lipoid pneumonia and infectious illnesses that occurred within three months of starting a KD.

\section{AUTHORS' CONCLUSIONS}

\section{Implications for practice}

The randomised controlled trials (RCTs) discussed in this review show promising results for the use of ketogenic diets (KDs) in epilepsy in children. However, the limited number of studies, small sample sizes and a sole adult study with short-term follow-up, result in a low to very low overall quality of evidence.

All studies comparing all KD variations reported adverse effects, from short-term gastrointestinal-related disturbances, to longerterm complications. The adverse effects associated with the MAD may initially appear lower than the classic KD, but further studies are required.

Attrition rates remained a problem in all KDs and across all studies, reasons for this being lack of observed efficacy and dietary intolerance.

One study found no significant difference in seizure reduction between gradual-onset and fasting-onset KD, which could prove 
cost-effective and time-saving. However, further large-scale studies are required.

The effect of KDs on quality of life, cognition and behaviour require further investigation.

There was a lack of evidence for the use of KDs in adults or infants with epilepsy, therefore, further research would be of benefit.

Other more palatable but related diets, such as the modified Atkins diet (MAD), may have a similar effect on seizure control as classical $\mathrm{KD}$ but this assumption requires further investigation.

For people who have medically intractable epilepsy or people who are not suitable for surgical intervention, KDs remain a valid option; however, further research is required.

\section{Implications for research}

Key areas for research identified by this review are as follows.

- Studies should address quality of life issues and cognitive changes using a validated scale.

- Further studies utilising economic modelling (quality-adjusted life years (QALYs)) would be of benefit.

- Consistency in outcomes across RCTs would be beneficial to research as a limitation of the present review was that meta- analysis was not possible. It may be beneficial for future RCTs to assess seizure frequency by means of seizure reduction (greater than $50 \%$ reduction in seizures) and seizure freedom (100\% reduction in seizures).

- Although shorter studies (e.g. 6 months) provide useful evidence for the efficacy of dietary interventions, it may be useful to assess the tolerability and adverse effects of such interventions in long-term studies that follow participants for over 12 months or preferably several years.

- Studies of the mechanisms of action could help determine which specific seizure types or syndromes respond better to the diets.

- Further studies should address other diets, particularly those that are less restrictive (such as the MAD).

- The present review highlighted a paucity of evidence for the use of the KD in adults and infants. Therefore, future studies should investigate the use and potential adverse effects of KDs, in adults and infants with epilepsy.

- Large-scale RCTs would be of benefit.

\section{A CKN OWLEDGEMENTS}

We would like to thank Pratima Giri and Jennifer Weston for contributions to previous versions of this review and Dr Elizabeth Neal for providing her expert opinion regarding included studies in this review. 


\section{R E F E R E N C E S}

\section{References to studies included in this review}

Bergqvist 2005 \{published data only\}

Bergqvist AG, Schall JI, Gallagher PR, Cnaan A, Stallings VA. Fasting versus gradual initiation of the ketogenic diet: a prospective, randomized clinical trial of efficacy. Epilepsia 2005;46(11):1810-9.

\section{El-Rashidy 2013 \{published data only\}}

El-Rashidy OF, Nassar MF, Abde-Hamid IA, Shatla RH, AbdelHamid HM, Gabr SS, et al. Modified Atkins diet vs classic ketogenic formula in intractable epilepsy. Acta Neurologica Scandinavica 2013;128(6):402-8.

Kim 2016 \{published data only\}

Kim JA, Yoon JR, Lee EJ, Lee JS, Kim JT, Kim HD, et al. Efficacy of the classic ketogenic and the modified Atkins diets in refractory childhood epilepsy. Epilepsia 2016;57(1):51-8.

\section{Kossoff 2007 \{published data only\}}

Kossoff EH, Turner Z, Bluml RM, Pyzik PL, Vining EP. A randomized, crossover comparison of daily carbohydrate limits using the modified Atkins diet. Epilepsy \& Behavior 2007;10(3):432-6.

\section{Lambrechts 2017 \{published data only\}}

IJff DM, Postulart D, Lambrechts DA, Majoie MH, de Kinderen RJ, Hendriksen JG, et al. Cognitive and behavioral impact of the ketogenic diet in children and adolescents with refractory epilepsy: a randomized controlled trial. Epilepsy \& Behavior 2016;60:153-7.

Kinderen RJ, Lambrechts DA, Wijnen BF, Postulart D, Aldenkamp AP, Majoie MH, et al. An economic evaluation of the ketogenic diet versus care as usual in children and adolescents with intractable epilepsy: an interim analysis. Epilepsia 2016;57(1):41-50.

* Lambrechts DA, Kinderen RJ, Vles JS, Louw AJ, Aldenkamp AP, Majoie HJ. A randomized controlled trial of the ketogenic diet in refractory childhood epilepsy. Acta Neurologica Scandinavica 2017;135(2):231-9

Wijnen BF, de Kinderen RJ, Lambrechts DA, Postulart D, Aldenkamp AP, Majoie MH, et al. Long-term clinical outcomes and economic evaluation of the ketogenic diet versus care as usual in children and adolescents with intractable epilepsy. Epilepsy Research 2017;132:91-9.

Neal 2008 \{published data only\}

Neal EG, Chaffe H, Schwartz RH, Lawson MS, Edwards N, Fitzsimmons $\mathrm{G}$, et al. A randomised trial of classical and medium-chain triglyceride ketogenic diets in the treatment of childhood epilepsy. Epilepsia 2009;50(5):1109-17.

* Neal EG, Chaffe H, Schwartz RH, Lawson MS, Edwards N, Fitzsimmons $\mathrm{G}$, et al. The ketogenic diet for the treatment of childhood epilepsy: a randomised controlled trial. Lancet Neurology 2008;7(6):500-6.
Raju 2011 \{published data only\}

Raju KNV, Gulati S, Kabra M, Agarwala A, Sharma S, Pandey RM, et al. Efficacy of 4:1 (classic) versus 2.5:1 ketogenic ratio diets in refractory epilepsy in young children: a randomized open labeled study. Epilepsy Research 2011;96(1-2):96-100.

\section{Seo 2007 \{published data only\}}

Seo JH, Lee YM, Lee JS, Kang HC, Kim HC. Efficacy and tolerability of the ketogenic diet according to lipid: nonlipid ratios - comparison of 3:1 with 4:1 diet. Epilepsia 2007;48(4):801-5.

\section{Sharma 2013 \{published data only\}}

Sharma S, Sankhyan N, Gulati S, Agarwala A. Use of the modified Atkins diet for treatment of refractory childhood epilepsy: a randomized controlled trial. Epilepsia 2013;54(3):481-6.

\section{Sharma 2016 \{published data only\}}

Sharma S, Goel S, Jain P, Agarwala A, Aneja S. Evaluation of a simplified modified Atkins diet for use by parents with low levels of literacy in children with refractory epilepsy: A randomized controlled trial. Epilepsy Research 2016;127:152-9.

\section{Zare 2017 \{published data only\}}

Zare M, Okhovat AA, Esmailzadeh A, Mehvari J, Najafi MR, Saadatnia M. Modified Atkins diet in adult with refractory epilepsy: A controlled randomized clinical trial. Iranian Journal of Neurology 2017;16(2):72-7.

\section{References to studies excluded from this review}

Dressler 2015 \{published data only\}

Dressler A, Trimmel-Schwahofer P, Reithofer E, Groppel G, Muhlebner A, et al. The ketogenic diet versus ACTH in the treatment of infantile spasms: A prospective randomised study. European Journal of Paeditatic Neurology 2015;19S:S1-S152.

Freeman 1999 \{published data only\}

Freeman JM, Vining EP. Seizures decrease rapidly after fasting: preliminary studies of the ketogenic diet. Archives of Pediatric and Adolescent Medicine 1999;153(9):946-9.

\section{Freeman 2009 \{published data only\}}

Freeman J, Vining E, Kossoff E, Pyzik P, Ye X, Goodman S. A blinded, crossover study of the efficacy of the ketogenic diet. Epilepsia 2009;50(2):322-5.

\section{Hemingway 2001 \{published data only\}}

Hemingway C, Freeman JM, Pillas DJ, Pyzik PL. The ketogenic diet: a 3- to 6-year follow-up of 150 children enrolled prospectively. Pediatrics 2001;108(4):898-905.

\section{Kang 2011 \{published data only\}}

Kang HC, Lee YJ, Lee JS, Lee EJ, Eom S, You SJ, et al. Comparison of short- versus long-term ketogenic diet for intractable infantile spasms. Epilepsia 2011;52(4):781-7. 
Singh 2015 \{published data only\}

Singh MK, Gulati S, Aggarwal A, Chakrabarty B, Pandey RM, Tripathi M. Efficacy of modified Atkins diet versus ketogenic diet in children with refractory epilepsy aged 1 year to 18 years: A randomised controlled trial. Epilepsia 2015;56(Suppl 1):245.

Smith 2011 \{published data only\}

Smith M, Politzer N, Macgarvie D, McAndrews MP, del Campo M. Efficacy and tolerability of the Modified Atkins Diet in adults with pharmacoresistant epilepsy: a prospective observational study. Epilepsia 2011;52(4):775-80.

\section{References to ongoing studies}

\section{CTRI/2015/07/006048 \{published data only\}}

CTRI/2015/07/006048. Modified Atkins diet in adolescence and adults with refractory epilepsy [Efficacy, safety and tolerability of modified Atkins diet in adolescence and adults with drug resistant epilepsy: a randomized controlled trial]. www.ctri.nic.in/Clinicaltrials/pmaindet2.php?trialid=11330 (first received 27 July 2015 ).

\section{Hulshof 2014 \{published data only\}}

Hulshof HM, Carpay JA, Jansen FE, Braun KPJ. The modified Atkins diet in patients with refractory epilepsy and severe intellectual disability - design of a randomized controlled trial. Epilepsia 2014;55:205.

\section{NCT02708030 \{published data only\}}

NCT02708030. Dietary Therapy In Epilepsy Treatment (DIETTrial): a randomised non-inferiority trial comparing KD, MAD \& LGIT for drug-resistant epilepsy (DIET) [Efficacy of Ketogenic Diet, Modified Atkins Diet and Low Glycemic Index Therapy Diet among children with drug resistant epilepsy: a randomised noninferiority trial]. clinicaltrials.gov/ct2/show/NCT02708030 (first received 15 March 2016).

\section{Additional references}

\section{Atkins 1972}

Atkins RC. Dr. Atkins' Diet Revolution: the high calorie way to stay thin forever. Philadelphia, PA: D McKay Co, 1972.

\section{Bough 2007}

Bough KJ, Rho JM. Anticonvulsant mechanisms of the ketogenic diet. Epilepsia 2007;48(1):43-58.

\section{Chang 2003}

Chang BS, Lowenstein DH. Epilepsy. New England Journal of Medicine 2003;349(13):1257-66.

\section{Coppola 2002}

Coppola G, Veggiotti P, Cusmai R, Bertoli S, Cardinali S, DionisiVici C, et al. The ketogenic diet in children, adolescents and young adults with refractory epilepsy: an Italian multicentric experience. Epilepsy Research 2002;48(3):221-7.

\section{de Kinderen 2016}

de Kinderen RJ, Lambrechts DA, Wijnen BF, Postulart D, Aldenkamp AP, Majoie MH, et al. An economic evaluation of the ketogenic diet versus care as usual in children and adolescents with intractable epilepsy: An interim analysis. Epilepsia 2016;57(1):41-50.

\section{DiMario 2002}

DiMario FJ, Holland J. The Ketogenic diet: a review of the experience at Connecticut Children's Medical Center. Pediatric Neurology 2002;26(4):288-92.

\section{Geyelin 1921}

Geyelin HR. Fasting as a method for treating epilepsy. Medical Record 1921;99:1037-9.

\section{Granata 2009}

Granata T, Marchi N, Carlton E, Ghosh C, Gonzalez-Martinez J, Alexopoulos AV, et al. Management of the patient with medically refractory epilepsy. Expert Review of Neurotherapeutics 2009;9(12):1791-802

\section{Guelpa 1911}

Guelpa G, Marie A. [La lutte contre l'epilepsie par la desintoxication et par la re-education alimentaire]. Revue de Therapie Medico-Chirurgide 1911;78:8-13.

\section{Guyatt 2008}

Guyatt GH, Oxman AD, Vist G, Kunz R, Falck-Ytter Y, AlonsoCoello P, et al. the GRADE Working Group. GRADE: an emerging consensus on rating quality of evidence and strength of recommendations. BMJ 2008;336(7650):924-6. [DOI: 10.1136/ bmj.39489.470347.AD; PUBMED: 18436948]

\section{Hauser 1990}

Hauser WA, Hesdorffer DC. Epilepsy: Frequency, Causes, and Consequences. New York: Demos Publications, 1990.

\section{Higgins 2011}

Higgins JP, Green S, editor(s). Cochrane Handbook for Systematic Reviews of Interventions Version 5.1.0 (updated March 2011). The Cochrane Collaboration, 2011. Available from handbook.cochrane.org.

\section{Hosain 2005}

Hosain SA, La Vega-Talbott M, Solomon GE. Ketogenic diet in pediatric epilepsy patients with gastrostomy feeding. Pediatric Neurology 2005;32(2):81-3.

\section{Huttenlocher 1971}

Huttenlocher PR, Wilbourn AJ, Signore BS. Medium-chain triglycerides as a therapy for intractable childhood epilepsy. Neurology 1971;21(11):1097-103.

\section{ljff 2016}

ljff DM, Postulart D, Lambrechts DA, Majoie MH, de Kinderen RJ, Hendriksen JG, et al. Cognitive and behavioural impact of the ketogenic diet in children and adolescents with refractory epilepsy: A randomised controlled trial. Epilepsy and Behavior 2016;60:153-7. 


\section{Kang 2005}

Kang HC, Kim YJ, Kim DW, Kim HD. Efficacy and safety of the ketogenic diet for intractable childhood epilepsy: Korean multicentric experience. Epilepsia 2005;46(2):272-9.

\section{Kirkham 2010}

Kirkham JJ, Dwan KM, Altman DG, Gamble C, Dodd S, Smyth R, et al. The impact of outcome reporting bias in randomised controlled trials on a cohort of systematic reviews. BMJ 2010;340:c365. [DOI: 10.1136/bmj.c365; PUBMED: 20156912]

\section{Kossoff 2005}

Kossoff EH, Thiele EA, Pfeifer HH, McGrogan JR, Freeman JM. Tuberous sclerosis complex and the ketogenic diet. Epilepsia 2005;46:1684-6.

\section{Kossoff 2008}

Kossoff EH, Rowley H, Sinha SR, Vining EPG. A prospective study of the modified Atkins diet for intractable epilepsy in adults. Epilepsia 2008;49(2):316-9.

\section{Lawn 2004}

Lawn ND, Bamlet WR, Radhakrishnan K, O'Brien PC, So EL. Injuries due to seizures in persons with epilepsy: a populationbased study. Neurology 2004;63(9):1565-70. [PUBMED: 15534237]

\section{Lefebvre 2011}

Lefebvre C, Manheimer E, Glanville J. Chapter 6: Searching for studies. In: Higgins JP, Green S, editor(s). Cochrane Handbook for Systematic Reviews of Interventions Version 5.1.0 (updated March 2011). The Cochrane Collaboration, 2011. Available from handbook.cochrane.org.

\section{Merritt 1938}

Merritt HH, Putnam TJ. Sodium diphenyl hydantoin in the treatment of convulsive disorders. JAMA 1938;111:1068-73.

\section{Moesk 2009}

Moesk A, Natour H, Neufeld MY, Shiff Y, Vaisman N. Ketogenic diet treatment in adults with refractory epilepsy: a prospective pilot study. Seizure 2009;18:30-3.

\section{Moher 2009}

Moher D, Liberati A, Tetzlaff J, Altman DG. The PRISMA Group. Preferred Reporting Items for Systematic Reviews and MetaAnalyses: The PRISMA Statement. BMJ 2009;339:2535.

\section{Neal 2009}

Neal EG, Chaffe H, Schwartz RH, Lawson MS, Edwards N, Fitzsimmons $\mathrm{G}$, et al. A randomized trial of classic and medium chain triglyceride ketogenic diets in the treatment of childhood epilepsy. Epilepsia 2009;50(5):1109-117.

\section{Nilsson 1999}

Nilsson L, Farahmond BY, Persson PG, Thiblin I, Tomson T. Risk factors for sudden unexpected death in epilepsy: a case control study. Lancet 1999;353:888-93.

\section{O'Connor 2014}

O'Connor SE, Richardson C, Trescher WH, Byler DL, Sather JD, Michael EH, et al. The ketogenic diet for the treatment of pediatric status epilepticus. Pediatric Neurology 2014;50:101-3.

\section{Schmidt 2002}

Schmidt D. The clinical impact of new antiepileptic drugs after a decade of use in epilepsy. Epilepsy Research 2002;50(1-2):21-32. [PUBMED: 12151114]

\section{Sharma 2009}

Sharma S, Gulati S, Agarwala A. Modified Atkins diet in childhood epilepsy: protocol. Clinicaltrials.gov 2009.

\section{Villeneuve 2004}

Villeneuve N. Quality-of-life scales for patients with drugresistant partial epilepsy [Quelles echelles de qualite de vie pour les patients ayant une epilepsie partielle pharmacoresistante]. Revue Neurologique 2004;160(Spec No 1):5S376-93. [PUBMED: 15331986]

\section{Wijnen 2017}

Wijnen BF, de Kinderen RJ, Lambrechts DA, Postulart D, Aldenkamp AP, Majoie MH, et al. Long-term clinical outcomes and economic evaluation of the ketogenic diet versus care as usual in children and adolescents with intractable epilepsy. Epilepsy Research 2017;132:91-9.

\section{Wilder 1921}

Wilder RM. The effects of ketonemia on course of epilepsy. Mayo Clinic Proceedings 1921;2:307-8.

\section{References to other published versions of this review \\ Levy 2003}

Levy RG, Cooper PP. Ketogenic diet for epilepsy. Cochrane Database of Systematic Reviews 2003, Issue 3. [DOI: 10.1002/14651858.CD001903]

\section{Levy 2012}

Levy RG, Cooper PN, Giri P, Weston J. Ketogenic diet and other dietary treatments for epilepsy. Cochrane Database of Systematic Reviews 2012, Issue 3. [DOI: 10.1002/14651858.CD001903.pub2]

\section{Martin 2016}

Martin K, Jackson CF, Levy RG, Cooper PN. Ketogenic diet and other dietary treatments for epilepsy. Cochrane Database of Systematic Reviews 2016, Issue 2. [DOI: 10.1002/14651858.CD001903.pub3]

* Indicates the major publication for the study 
CHARACTERISTICS OF STUDIES

Characteristics of included studies [ordered by study ID]

Bergqvist 2005

Methods Prospective, randomised, single-centre study comparing Fast KD and Grad KD over a 3-month period. Baseline data of seizure activity was collected 28 days prior to diet initiation

Participants 48 children, 24 in each of the 2 arms, aged 1-14 years (mean 5.3, SD 2.7 years), having $\geq 1$ seizures per 28 days, tried at least 3 AEDs and a discontinuation of steroidal medication 3 months previous. Study undertaken in Philadelphia, USA. All generalised and partial seizures included

\begin{tabular}{ll}
\hline Interventions & Speed of introduction of KD: Fast KD (<48 hour fast, followed by 4:1 KD with increase in portion size \\
& over 6 days) or Grad KD (gradual increase in KD ratio from 1:1 to 4:1 over 6 days) \\
\hline Outcomes & Proportion of participants with $>50 \%$ seizure reduction in target seizure type \\
- Level of ketosis & Adverse effects \\
Notes & In the first 6 days of the KD trial, 2 participants dropped out, 1 with pancreatitis (Fast KD) and 1 due to \\
& viral gastrointestinal illness (Grad KD). 3 further dropouts occurred in the Fast KD prior to 3 months' fol- \\
& low-up, 1 due to respiratory distress and 2 due to lack of efficacy. In the Grad KD group, 1 participant \\
& withdrew due to lack of efficacy. \\
& Exclusion criteria: children with metabolic disorders, genetic disorders and known or suspected neu- \\
rodegenerative disorders. $42 \%$ of children included in the study had cerebral palsy. \\
This study was supported in part by RRK-23 16074 and General Clinical Research Center (MO1RR00240), \\
the Nutrition Center of the Children's Hospital of Philadelphia, P30 HD26979, and the Catharine Brown \\
Foundation.
\end{tabular}

\section{Risk of bias}

\begin{tabular}{lll}
\hline Bias & Authors' judgement & Support for judgement \\
\hline $\begin{array}{l}\text { Random sequence genera- } \\
\text { tion (selection bias) }\end{array}$ & Low risk & $\begin{array}{l}\text { Stratified by age (1-2 years and 2-14 years); randomisation in permuted blocks } \\
\text { of random size (2-4) }\end{array}$ \\
\hline $\begin{array}{l}\text { Allocation concealment } \\
\text { (selection bias) }\end{array}$ & Low risk & $\begin{array}{l}\text { Randomisation through permuted blocks of random size of groups of 2 or } 4 \\
\text { participants in order to prevent any ability to guess the next assignment }\end{array}$ \\
\hline $\begin{array}{l}\text { Blinding (performance } \\
\text { bias and detection bias) } \\
\text { All outcomes }\end{array}$ & High risk & Not blinded \\
\hline $\begin{array}{l}\text { Incomplete outcome data } \\
\text { (attrition bias) }\end{array}$ & Unclear risk & Similar attrition rate in both groups, numbers too small for statistical analysis \\
\hline $\begin{array}{l}\text { Selective reporting (re- } \\
\text { porting bias) }\end{array}$ & Unclear risk & Protocol unavailable \\
\hline $\begin{array}{l}\text { Other bias } \\
\text { L pow risk }\end{array}$ & All participants admitted received same care \\
\hline
\end{tabular}


El-Rashidy 2013

\begin{tabular}{|c|c|}
\hline Methods & $\begin{array}{l}\text { Single-centre randomised controlled trial to comparing two different dietary interventions (MAD and } \\
\text { classic KD in form of 4:1 liquid diet) and a control group (AED polytherapy). }\end{array}$ \\
\hline Participants & $\begin{array}{l}40 \text { children aged } 12-36 \text { months (mean } 27.13 \text {, SD 6.63) with symptomatic intractable epilepsy. Study un- } \\
\text { dertaken in Egypt }\end{array}$ \\
\hline Interventions & $\begin{array}{l}\text { Participants were randomised into } 1 \text { of } 3 \text { groups; MAD ( } 15 \text { participants), KD ( } 10 \text { participants) and con- } \\
\text { trol (polytherapy) ( } 15 \text { participants). Data were collected at } 3 \text { and } 6 \text { months }\end{array}$ \\
\hline Outcomes & $\begin{array}{l}\text { - Reduction in seizure frequency } \\
\text { - Adverse effects } \\
\text { - Attrition rate }\end{array}$ \\
\hline \multirow[t]{4}{*}{ Notes } & $\begin{array}{l}2 \text { participants in the MAD group dropped out of the trial as they could not accept the diet and experi- } \\
\text { enced weight loss. From the results, it could be inferred that these participants dropped out between } \\
\text { the } 3 \text { - and } 6 \text {-month reviews. } 2 \text { participants from the classic KD group dropped out due to intolerance; } \\
\text { however, it was unclear when these participants dropped out. }\end{array}$ \\
\hline & $\begin{array}{l}\text { Exclusion criteria: children < } 1 \text { year, diagnosed with idiopathic epilepsy or with other systemic chronic } \\
\text { conditions }\end{array}$ \\
\hline & $4: 1$ refers to $4 \mathrm{~g}$ fat to $1 \mathrm{~g}$ of carbohydrate and protein combined. \\
\hline & $\begin{array}{l}\text { No external funding support was received for this study beyond the treating hospital (Children's hospi- } \\
\text { tal, Faculty of Medicine, Ain Shams University). }\end{array}$ \\
\hline
\end{tabular}

\section{Risk of bias}

\begin{tabular}{lll}
\hline Bias & Authors' judgement & Support for judgement \\
\hline $\begin{array}{l}\text { Random sequence genera- } \\
\text { tion (selection bias) }\end{array}$ & Unclear risk & $\begin{array}{l}\text { Although the paper stated that participants were 'randomly assigned', there } \\
\text { was no information regarding how the randomisation sequence was generat- } \\
\text { ed. }\end{array}$ \\
\hline $\begin{array}{l}\text { Allocation concealment } \\
\text { (selection bias) }\end{array}$ & Unclear risk & $\begin{array}{l}\text { There was no information suggesting whether allocation was concealed or } \\
\text { not. }\end{array}$ \\
\hline $\begin{array}{l}\text { Blinding (performance } \\
\text { bias and detection bias) } \\
\text { All outcomes }\end{array}$ & High risk & $\begin{array}{l}\text { Blinding was not discussed in this paper but considering the design of the } \\
\text { study, binding of participants and study personnel does not seem possible. }\end{array}$ \\
\hline $\begin{array}{l}\text { Incomplete outcome data } \\
\text { (attrition bias) }\end{array}$ & High risk & $\begin{array}{l}\text { Study attrition was reported but ITT analysis was not carried out. Reasons for } \\
\text { dropouts were likely to be related to interventions. }\end{array}$ \\
\hline $\begin{array}{l}\text { Selective reporting (re- } \\
\text { porting bias) }\end{array}$ & Unclear risk & $\begin{array}{l}\text { Emailed author regarding protocol, awaiting response from co-authors. Proto- } \\
\text { col currently unavailable }\end{array}$ \\
\hline $\begin{array}{l}\text { Other bias } \\
\text { nigh }\end{array}$ & High risk & $\begin{array}{l}\text { No measure of seizure frequency reported at baseline. 20\% of participants in } \\
\text { the classic KD group had infantile spasms. }\end{array}$ \\
\hline
\end{tabular}

Kim 2016

Methods $\quad$ Prospective, single-centre, randomised trial to compare MAD (75\% energy restriction) to classic KD (4:1 ratio). Four week baseline period completed 
Kim 2016 (Continued)

Participants 104 participants aged 1 to 18 years, with drug-resistant epilepsy, experiencing more than 4 seizures per month, with treatment failure following 2 or more AEDs. Study was conducted in Korea

Interventions

Randomised into 1 of 2 groups; MAD ( $10 \mathrm{~g}$ carbohydrate per day for the first month, followed by increase to $10 \%$ of total energy requirements, with energy restriction to $75 \%$ of recommended daily intake) and classic KD (4:1 ratio) for a 6-month period

\begin{tabular}{ll}
\hline Outcomes & - Seizure reduction \\
- Seziure freedom \\
- Adverse events \\
- Compliance \\
- Attrition
\end{tabular}

Notes

At 3 months 12 participants had discontinued the classic KD; 1 due to inefficacy, 7 due to intolerance and 4 due to side effects. In the MAD group 6 participants had discontinued diet; 3 due to inefficacy, 2 due to intolerance and 1 due to side effects. By 6 months a further 5 participants discontinued to classic KD; 1 due to inefficacy, 1 due to intolerance and 3 due to side effects. In the MAD group 11 had discontinued diet; 3 due to inefficacy, 6 due to intolerance and 2 due to side effects.

Exclusion criteria: history of previous diet therapy, hyperlipidaemia, renal calculi, any other medical contraindications for diet therapy

4:1 refers to $4 \mathrm{~g}$ fat to $1 \mathrm{~g}$ of carbohydrate and protein combined.

This study was supported financially by the National Research Foundation of Korea (NRF) funded by the Ministry of Education, Science and Technology.

\section{Risk of bias}

\begin{tabular}{|c|c|c|}
\hline Bias & Authors' judgement & Support for judgement \\
\hline $\begin{array}{l}\text { Random sequence genera- } \\
\text { tion (selection bias) }\end{array}$ & Low risk & $\begin{array}{l}\text { Stratified permuted block randomisation. Minimisation method used to adjust } \\
\text { for age (1-2 years, 2-6 years, 6-18 years) }\end{array}$ \\
\hline $\begin{array}{l}\text { Allocation concealment } \\
\text { (selection bias) }\end{array}$ & Unclear risk & Unclear \\
\hline $\begin{array}{l}\text { Blinding (performance } \\
\text { bias and detection bias) } \\
\text { All outcomes }\end{array}$ & Unclear risk & Unclear \\
\hline $\begin{array}{l}\text { Incomplete outcome data } \\
\text { (attrition bias) }\end{array}$ & Low risk & Study attrition reported and unclear if ITT analysis carried out \\
\hline $\begin{array}{l}\text { Selective reporting (re- } \\
\text { porting bias) }\end{array}$ & Unclear risk & Protocol unavailable \\
\hline Other bias & High risk & $\begin{array}{l}\text { An energy restriction of } 75 \% \text { of recommended daily intake applied to MAD } \\
\text { group and not classical KD group. Significant difference noted in the under 2's } \\
\text { in favour of the classical KD likely to be underpowered due to subanalysis }\end{array}$ \\
\hline
\end{tabular}

Kossoff 2007

Methods Prospective, randomised, cross-over controlled trial to compare daily carbohydrate limits of $10 \mathrm{~g}$ and $20 \mathrm{~g}$, using the MAD over a 6 -month period 
Kossoff 2007 (Continued)

Participants 20 children, aged 3-18 years with intractable epilepsy, with a prior use of at least 2 AEDs and experiencing daily seizures. All seizure types included. Study conducted in Baltimore USA

Interventions

MAD with randomisation either to $10 \mathrm{~g}$ (10 children) or $20 \mathrm{~g}$ (10 children) of carbohydrate and crossover at 3 months

\begin{tabular}{ll}
\hline Outcomes & Seizure reduction \\
& - Level of ketosis \\
& Tolerability
\end{tabular}

Notes

$3(30 \%)$ participants dropped out in the $10 \mathrm{~g}$ carbohydrate/day group and $5(50 \%)$ participants in the 20 g carbohydrate/day group by 6 months, no significance was found between the groups $(P=0.33)$. Reasons for dropout were not stated.

Exclusion criteria: children with prior experience of the diet for $>7$ days, hypercholesterolaemia, kidney dysfunction, $\mathrm{BMI}<3 \%$ for age and children with heart disease.

Funding support for this study was not stated.

\section{Risk of bias}

\begin{tabular}{lll}
\hline Bias & Authors' judgement & Support for judgement \\
\hline $\begin{array}{l}\text { Random sequence genera- } \\
\text { tion (selection bias) }\end{array}$ & Unclear risk & Method not stated \\
\hline $\begin{array}{l}\text { Allocation concealment } \\
\text { (selection bias) }\end{array}$ & Unclear risk & Not stated \\
\hline $\begin{array}{l}\text { Blinding (performance } \\
\text { bias and detection bias) } \\
\text { All outcomes }\end{array}$ & High risk & Non-blinded \\
\hline $\begin{array}{l}\text { Incomplete outcome data } \\
\text { (attrition bias) }\end{array}$ & Unclear risk & $\begin{array}{l}\text { Greater attrition rate in 20 g carbohydrate group but not significant. 3/10 in } \\
10 \text { g carbohydrate and 5/10 in 20 g carbohydrate group did not complete the } \\
\text { study. P = 0.33. No ITT analysis completed }\end{array}$ \\
\hline $\begin{array}{l}\text { Selective reporting (re- } \\
\text { porting bias) }\end{array}$ & Low risk & Protocol received. No evidence to suggest selective reporting \\
\hline \begin{tabular}{l} 
Other bias \\
\hline
\end{tabular} & Low risk & Same care to both groups \\
\hline
\end{tabular}

Lambrechts 2017

Methods
MCT KD) to a control group over a 4-month period. Follow-on studies then compared long-term clini-
cal outcomes at 16 months, cognitive and behavioural impacts and an economic evaluation. A 4-week
baseline period was completed.

Participants

57 participants aged 1 to 18 years with drug-resistant epilepsy, seizures not adequately controlled by 2 or more AEDs and surgical remedial causes of epilepsy not viable. Study was conducted in the Netherlands

\begin{tabular}{ll}
\hline Interventions & Randomised into 1 of 2 groups; KD (classic KD and MCT KD) and control for a four-month period \\
\hline Outcomes & - Seizure reduction
\end{tabular}


Lambrechts 2017 (Continued)
- Adverse events
- Attrition
- Quality of life
- Cost-effectiveness
- Cognitive and behavioural changes

Notes

7 participants in the KD group dropped out by 4 months; 1 due to compliance, 1 due to ineffectiveness, 1 due to ineffectiveness combined with adverse events, 2 due to adverse events alone, 1 due to change in seizure pattern and 1 due to withdrawn consent. In the control group 9 participants dropped out, all 9 due to dissatisfaction with randomisation arm. By 16 months, a further 4 participants had discontinued KD; 2 due to compliance, 1 due to ineffectiveness and 1 due to ineffectiveness combined with adverse events. Data at 16 months for the control group is not presented as the control arm had no option to commence KD after the initial 4-month control period was completed.

Exclusion criteria: medical contraindications, behavioural or motivational problems that would preclude compliance.

The study was supported financially by the Netherlands Organisation for Health Research and Development.

\begin{tabular}{|c|c|c|}
\hline Risk of bias & & \\
\hline Bias & Authors' judgement & Support for judgement \\
\hline $\begin{array}{l}\text { Random sequence genera- } \\
\text { tion (selection bias) }\end{array}$ & Low risk & ALEA, minimisation method of sequence generation \\
\hline $\begin{array}{l}\text { Allocation concealment } \\
\text { (selection bias) }\end{array}$ & Unclear risk & Not stated \\
\hline $\begin{array}{l}\text { Blinding (performance } \\
\text { bias and detection bias) } \\
\text { All outcomes }\end{array}$ & High risk & $\begin{array}{l}\text { Study did not report whether blinding was undertaken although it seems from } \\
\text { the design of the study that blinding would not be possible. }\end{array}$ \\
\hline $\begin{array}{l}\text { Incomplete outcome data } \\
\text { (attrition bias) }\end{array}$ & Low risk & Study attrition reported and ITT analysis carried out \\
\hline $\begin{array}{l}\text { Selective reporting (re- } \\
\text { porting bias) }\end{array}$ & Low risk & Protocol published. No evidence to suggest selective reporting bias \\
\hline Other bias & High risk & $\begin{array}{l}\text { Excluded participants with motivational or behavioural problems. Baseline } \\
\text { differences in mood and behaviour scores, gender balance and seizure fre- } \\
\text { quency (no significance value reported to fully assess extent). Gastrointestinal } \\
\text { problems greater at baseline in KD group compared to control ( } P<0.05) \text {. Un- } \\
\text { der powered to assess QALYs and tool extrapolated from adult tariffs. }\end{array}$ \\
\hline
\end{tabular}

\section{Neal 2008}

\begin{tabular}{ll} 
Methods & $\begin{array}{l}\text { Prospective, randomised, non-blinded, controlled trial comparing KD (classic (4:1) and MCT combined) } \\
\text { to controls over a 3-month period, with a follow-on study then compared classic KD versus MCT KD } \\
\text { over a 12-month period. 4-week seizure baseline completed }\end{array}$ \\
\hline Participants & $\begin{array}{l}145 \text { children (aged 2-16 years), with daily seizures and }>7 \text { seizures/week, who had not responded to } \geq \\
2 \text { AEDs who had not previously been treated with a KD. Study conducted in the UK. All seizure types in- } \\
\text { cluded }\end{array}$
\end{tabular}


Neal 2008 (Continued)

Interventions $\quad$ Participants were randomised to commence a KD (either classic or MCT) immediately (73 participants) or after a further 3 months of seizure recording (control group, 72 participants). Those in the KD arm were then randomised to receive classical KD or MCT

\begin{tabular}{ll}
\hline Outcomes & - Reduction in seizure frequency \\
& - Tolerability
\end{tabular}

Notes

Of the 65 who commenced the diet, 10 dropped out. Of these, 6 had poor dietary tolerance, 3 withdrew due to parental unhappiness, 1 increased seizures and 1 excluded due to inadequate data. In the control group, 15 participants were excluded due to inadequate data.

Exclusion criteria: hyperlipidaemia, renal stones or organic acid deficiency syndromes.

4:1 refers to $4 \mathrm{~g}$ fat to $1 \mathrm{~g}$ of carbohydrate and protein combined.

This study received financial support from HSA, Smiths Charity, Scientific Hospital Supplies, and the Milk Development Council. University College London Institute of Child Health received funding as a National Institute for Health and Research Specialist Biomedical Research Centre.

\section{Risk of bias}

\begin{tabular}{lll}
\hline Bias & Authors' judgement & Support for judgement \\
\hline $\begin{array}{l}\text { Random sequence genera- } \\
\text { tion (selection bias) }\end{array}$ & Low risk & Minimisation method with stratification \\
\hline $\begin{array}{l}\text { Allocation concealment } \\
\text { (selection bias) }\end{array}$ & Low risk & Computer programme \\
\hline $\begin{array}{l}\text { Blinding (performance } \\
\text { bias and detection bias) } \\
\text { All outcomes }\end{array}$ & High risk & Non-blinded \\
\hline $\begin{array}{l}\text { Incomplete outcome data } \\
\text { (attrition bias) }\end{array}$ & High risk & High level of missing data in control group \\
\hline $\begin{array}{l}\text { Selective reporting (re- } \\
\text { porting bias) }\end{array}$ & Low risk & Initial application protocol received \\
\hline \begin{tabular}{l} 
Other bias \\
\hline
\end{tabular} & Low risk & Same care to both groups \\
\hline
\end{tabular}

\section{Raju 2011}

\begin{tabular}{ll}
\hline Methods & $\begin{array}{l}\text { Randomised, non-blinded, open-label, parallel controlled trial, to compare a 4:1 and a 2.5:1 ratio KD } \\
\text { over a 3-month period }\end{array}$ \\
\hline Participants & $\begin{array}{l}38 \text { children aged } 6 \text { months to } 5 \text { years, with drug-resistant epilepsy, at least 2 seizures/month, despite } \\
\text { appropriate use of at least } 2 \text { AEDs and at least } 1 \text { newer AED } \\
\text { Study undertaken in India }\end{array}$ \\
\hline Interventions & $\begin{array}{l}\text { Participants were randomised into } 1 \text { of } 2 \text { groups; a 4:1 ratio KD (19 participants) and 2.5:1 KD (19 partic- } \\
\text { ipants) and followed for 3 months }\end{array}$ \\
\hline Outcomes & - Adverse effects \\
\hline
\end{tabular}


Raju 2011 (Continued)

Notes
3 participants in each group dropped out of the study. Reasons for dropout in 4:1 KD group were refusal to eat, unsatisfactory seizure control and non-acceptance by other family members. In 2.5:1 KD group,

2 participants dropped out due to unsatisfactory seizure control and 1 due to refusal to eat.

Exclusion criteria: known or suspected inborn errors of metabolism, systemic illness or surgical remediable causes of epilepsy.

$4: 1$ refers to $4 \mathrm{~g}$ fat to $1 \mathrm{~g}$ of carbohydrate and protein combined. $2.5: 1$ refers to $2.5 \mathrm{~g}$ fat to $1 \mathrm{~g}$ of carbohydrate and protein combined.

No funding was received for this study.

\section{Risk of bias}

\begin{tabular}{lll}
\hline Bias & Authors' judgement & Support for judgement \\
\hline $\begin{array}{l}\text { Random sequence genera- } \\
\text { tion (selection bias) }\end{array}$ & Low risk & Sequence generation was computer generated \\
\hline $\begin{array}{l}\text { Allocation concealment } \\
\text { (selection bias) }\end{array}$ & Low risk & Opaque sealed envelopes were used to conceal allocation. \\
\hline $\begin{array}{l}\text { Blinding (performance } \\
\text { bias and detection bias) } \\
\text { All outcomes }\end{array}$ & High risk & Study was unblinded \\
\hline $\begin{array}{l}\text { Incomplete outcome data } \\
\text { (attrition bias) }\end{array}$ & Low risk & $\begin{array}{l}\text { Attrition was reported and was fairly equal across the groups. ITT analysis car- } \\
\text { ried out }\end{array}$ \\
\hline $\begin{array}{l}\text { Selective reporting (re- } \\
\text { porting bias) }\end{array}$ & Unclear risk & Protocol unavailable \\
\hline \begin{tabular}{l} 
Other bias \\
\hline
\end{tabular} & High risk & Participants were all < 18 years of age and there was a high rate of comorbidity \\
\hline
\end{tabular}

Seo 2007

$\begin{array}{ll}\text { Methods } & \text { Single-centre randomised controlled trial, to compare 3:1 and 4:1 KD. Baseline period lasted } 2 \text { months. } \\ \text { After a 3-month period of the diet, participants who were seizure free in the 4:1 group were recom- } \\ \text { mended to change to a 3:1 ratio, and participants who were not seizure free in the 3:1 group were rec- } \\ \text { ommended to change to a 4:1 ratio and were re-evaluated after a further } 3 \text { months. }\end{array}$

\begin{tabular}{ll}
\hline Participants & $\begin{array}{l}76 \text { children (aged } 4 \text { months to } 16 \text { years), with }>4 \text { seizures/month and seizures were not controlled by at } \\
\text { least } 3 \text { AEDs. Study completed in Korea. All seizure types included }\end{array}$ \\
\hline Interventions & $\begin{array}{l}\text { Participants were randomised into } 2 \text { groups, 4:1 KD group (40 participants) and 3:1 KD group (36 partic- } \\
\text { ipants) and the diet was followed for } 3 \text { months }\end{array}$ \\
\hline Outcomes & Seizure reduction rate \\
- Tolerability
\end{tabular}


4:1 refers to $4 \mathrm{~g}$ fat to $1 \mathrm{~g}$ of carbohydrate and protein combined. $3: 1$ refers to $3 \mathrm{~g}$ fat to $1 \mathrm{~g}$ carbohydrate and protein combined

This study was financially supported by Yonsei University Research Fund of 2003.

\section{Risk of bias}

\begin{tabular}{|c|c|c|}
\hline Bias & Authors' judgement & Support for judgement \\
\hline $\begin{array}{l}\text { Random sequence genera- } \\
\text { tion (selection bias) }\end{array}$ & Unclear risk & $\begin{array}{l}\text { Although study stated that participants were randomly assigned to each } \\
\text { group, there was no information regarding how randomisation was achieved }\end{array}$ \\
\hline $\begin{array}{l}\text { Allocation concealment } \\
\text { (selection bias) }\end{array}$ & Unclear risk & Insufficient information \\
\hline $\begin{array}{l}\text { Blinding (performance } \\
\text { bias and detection bias) } \\
\text { All outcomes }\end{array}$ & High risk & $\begin{array}{l}\text { Study did not report whether blinding was undertaken although it seems from } \\
\text { the design of the study that blinding would not be possible }\end{array}$ \\
\hline $\begin{array}{l}\text { Incomplete outcome data } \\
\text { (attrition bias) }\end{array}$ & Low risk & $\begin{array}{l}\text { Number of dropouts and reasons for dropouts were reported and an ITT analy- } \\
\text { sis was completed }\end{array}$ \\
\hline $\begin{array}{l}\text { Selective reporting (re- } \\
\text { porting bias) }\end{array}$ & Unclear risk & Protocol unavailable \\
\hline Other bias & Low risk & No other sources of bias identified \\
\hline
\end{tabular}

\section{Sharma 2013}

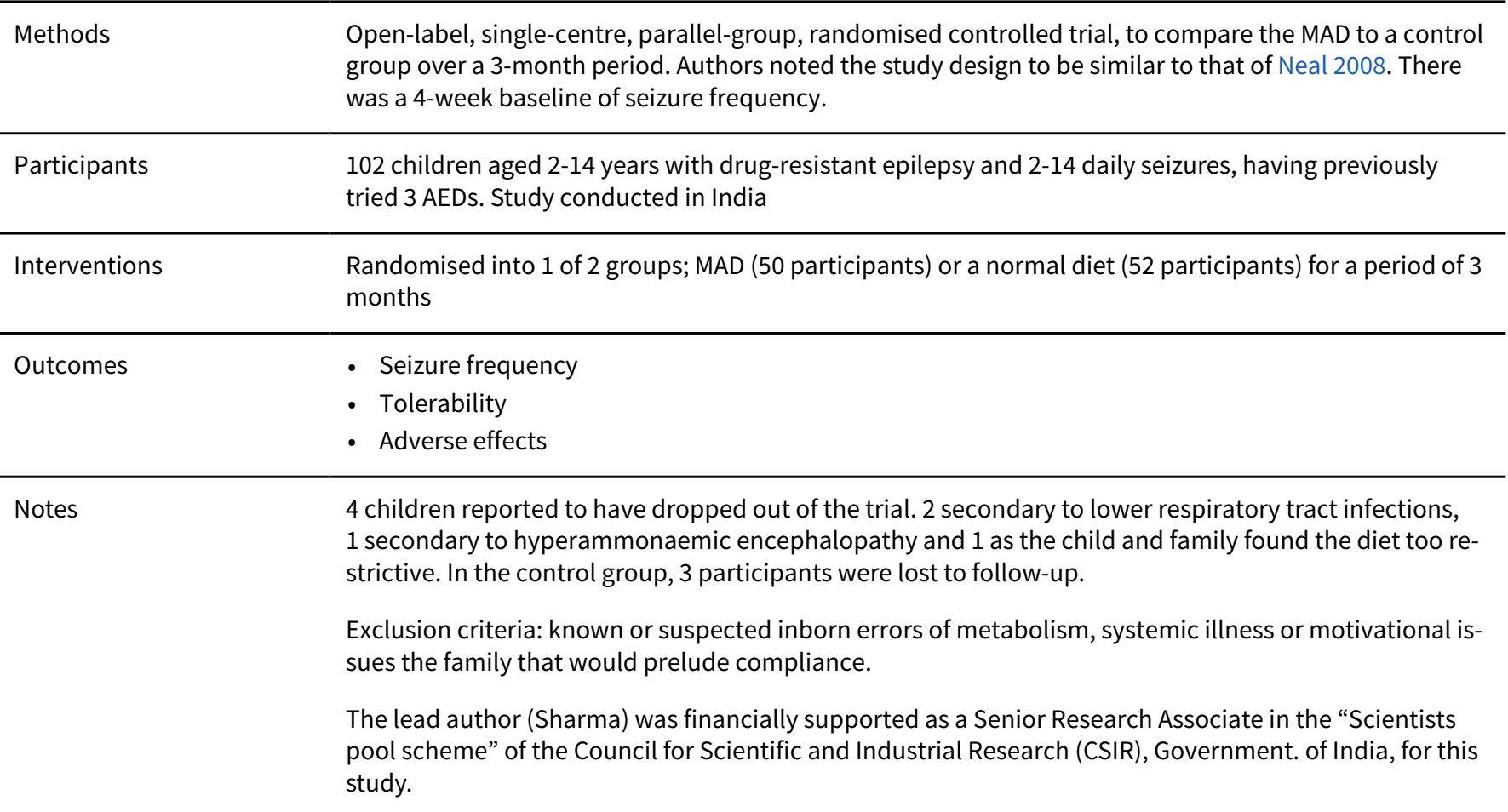

\section{Risk of bias}


Sharma 2013 (Continued)

\begin{tabular}{lll} 
Bias & Authors' judgement & Support for judgement \\
\hline $\begin{array}{l}\text { Random sequence genera- } \\
\text { tion (selection bias) }\end{array}$ & Low risk & Randomisation sequence was computer generated \\
\hline $\begin{array}{l}\text { Allocation concealment } \\
\text { (selection bias) }\end{array}$ & Low risk & Opaque sealed envelopes were used to conceal allocation. \\
\hline $\begin{array}{l}\text { Blinding (performance } \\
\text { bias and detection bias) } \\
\text { All outcomes }\end{array}$ & High risk & Unblinded \\
\hline $\begin{array}{l}\text { Incomplete outcome data } \\
\text { (attrition bias) }\end{array}$ & Low risk & Study attrition reported an ITT analysis carried out \\
\hline $\begin{array}{l}\text { Selective reporting (re- } \\
\text { porting bias) }\end{array}$ & Low risk & $\begin{array}{l}\text { Protocol available 15 August 2015 (clinicaltrials.gov/ct2/show/NCT00836836; } \\
\text { Sharma 2009) }\end{array}$ \\
\hline \begin{tabular}{l} 
Other bias \\
\hline
\end{tabular} & High risk & Excluded participants where motivational issues within the family were noted \\
\hline
\end{tabular}

Sharma 2016

$\begin{array}{ll}\text { Methods } & \text { Prospective, randomised, non-blinded controlled trial to compare sMAD to control (normal diet). Four- } \\ \text { week baseline period completed }\end{array}$

\begin{tabular}{ll}
\hline Participants & $\begin{array}{l}81 \text { participants aged 2-14 years, with drug-resistant epilepsy, experiencing daily seizures (or more than } \\
7 \text { seizures per week) despite } 2 \text { or more AEDs. Study was conducted in India }\end{array}$ \\
\hline Interventions & $\begin{array}{l}\text { Randomised into } 1 \text { of } 2 \text { groups; sMAD (10 g carbohydrate per day, delivered with simplified dietary } \\
\text { methods) and control (normal diet) for a 3-month period }\end{array}$ \\
\hline Outcomes & Seizure reduction \\
- Adverse events & Non-seizure domains \\
- Tolerability
\end{tabular}

\section{Risk of bias}

\begin{tabular}{lll}
\hline Bias & Authors' judgement & Support for judgement \\
\hline $\begin{array}{l}\text { Random sequence genera- } \\
\text { tion (selection bias) }\end{array}$ & Low risk & $\begin{array}{l}\text { Variable block randomisation (2, } 6 \text { and } 6 \text { block sizes), using computer generat- } \\
\text { ed randomisation sequence }\end{array}$ \\
\hline $\begin{array}{l}\text { Allocation concealment } \\
\text { (selection bias) }\end{array}$ & Low risk & Opaque sealed envelopes \\
\hline
\end{tabular}


Sharma 2016 (Continued)

\begin{tabular}{lll}
$\begin{array}{l}\text { Blinding (performance } \\
\text { bias and detection bias) } \\
\text { All outcomes }\end{array}$ & High risk & Unblinded \\
\hline $\begin{array}{l}\text { Incomplete outcome data } \\
\text { (attrition bias) }\end{array}$ & Low risk & Study attrition reported and ITT analysis carried out \\
\hline $\begin{array}{l}\text { Selective reporting (re- } \\
\text { porting bias) }\end{array}$ & Low risk & Protocol received \\
\hline $\begin{array}{l}\text { Other bias } \\
\text { Low risk }\end{array}$ & $\begin{array}{l}\text { A subjective, non-validated tool was used to assess alertness, speech, sleep- } \\
\text { ing, social and behavioural changes, results of which not included in this re- } \\
\text { view }\end{array}$
\end{tabular}

\section{Zare 2017}

Methods

Prospective, randomised, non-blinded, controlled trial to compare MAD to a control over a 2-month period

\begin{tabular}{ll}
\hline Participants & 66 adult participants aged 18 years or over, with drug-resistant epilepsy (2 or more AEDs and 2 or more \\
seizures per month). Study was conducted in Iran
\end{tabular}

Randomised into 1 of 2 groups; MAD (carbohydrates limited to 15 g per day; approximate macronutri-
ent intakes as a percentage of total energy: $4 \%$ to $6 \%$ carbohydrate, $20 \%$ to $30 \%$ protein, $60 \%$ to $70 \%$
fat) and a control for a 2-month period.

\begin{tabular}{ll}
\hline Outcomes & Seizure reduction \\
& Adverse events \\
\hline Notes & At 2 months 12 participants dropped out of the MAD arm, all due to non-compliance \\
& $\begin{array}{l}\text { Exclusion criteria: prior use of the Atkins' diet or MAD for } 1 \text { week or more, use of } \mathrm{KD} \text { within the last year, } \\
\text { heart disease, renal disease, hypercholesterolaemia, coronary heart diease, cerebral vascular disease, } \\
\text { peripheral vascular disease, atherosclerosis, myocardial infarction, pregnancy, } \mathrm{BMI}<18.5 \mathrm{~kg} / \mathrm{m}^{2}, \mathrm{sta}- \\
\text { tus epilepticus in last } 6 \text { months and 2-week seizure-free period in last } 6 \text { months }\end{array}$ \\
& $\begin{array}{l}\text { The study was supported by the Plastic Surgery Research Centre, Isfahan University of Medical } \\
\text { Sciences, Isfahan. }\end{array}$ \\
\hline
\end{tabular}

\section{Risk of bias}

\begin{tabular}{lll}
\hline Bias & Authors' judgement & Support for judgement \\
\hline $\begin{array}{l}\text { Random sequence genera- } \\
\text { tion (selection bias) }\end{array}$ & Low risk & Random number table \\
\hline $\begin{array}{l}\text { Allocation concealment } \\
\text { (selection bias) }\end{array}$ & Unclear risk & Not stated \\
\hline $\begin{array}{l}\text { Blinding (performance } \\
\text { bias and detection bias) } \\
\text { All outcomes }\end{array}$ & High risk & Unblinded \\
\hline
\end{tabular}

Incomplete outcome data Low risk Study attrition reported and ITT analysis carried out
(attrition bias)


Zare 2017 (Continued)

Selective reporting (re- Unclear risk Protocol unavailable porting bias)

Other bias

High risk
Numerical errors with the article. No power calculation stated. Low levels of urinary ketosis achieved, may impact efficacy data. Unknown if baseline period completed prior to commencing diet

AED: antiepileptic drug; BMI: body mass index; Fast FD: fasting-onset ketogenic diet; Grad KD: gradual-onset ketogenic diet; ITT: intentionto-treat; KD: ketogenic diet; MAD: modified Atkins diet; MCT: medium-chain triglyceride; QALYs: quality-adjusted life years; SD: standard deviation; SMAD: simplified modified Atkins diet.

Characteristics of excluded studies [ordered by study ID]

\begin{tabular}{ll}
\hline Study & Reason for exclusion \\
\hline Dressler 2015 & Infantile spasms \\
\hline Freeman 1999 & Outcome measures did not match inclusion criterion as duration of study was 12 days \\
\hline Freeman 2009 & Study was very brief and lasted only 12 days - duration of the study did not fit entry criteria \\
\hline Hemingway 2001 & Not a randomised controlled trial \\
\hline Kang 2011 & $\begin{array}{l}\text { Drug-resistant infantile spasm population, outcome measures did not match inclusion criteria for } \\
\text { this review }\end{array}$ \\
\hline Singh 2015 & Abstract only. Unable to obtain further data \\
\hline Smith 2011 & Not a randomised controlled trial \\
\hline
\end{tabular}

Characteristics of ongoing studies [ordered by study ID]

CTRI/2015/07/006048

\begin{tabular}{ll}
\hline Trial name or title & Modified Atkins diet in adolescence and adults with drug-resistant epilepsy \\
\hline Methods & An unblinded, randomised control trial \\
\hline Participants & Aimed to recruit 160 people, aged 10 to 55 years, with drug-resistant epilepsy. Inlcuded partici- \\
& pants experiencing persistent, daily countable seizures (more than 2 per month for 6 months), will- \\
& ing to attend regular follow-up and maintain seizure frequency accurately and willing to perform \\
& induction phase of diet. Potencial participants excluded due if less than 10 years of age, surgical- \\
& ly remediable causes of epilepsy, clinical features of inborn metabolism, suspicion of a metabolic \\
& disorder, refusal to give consent, tried ketogenic diet in past year, BMl $<18$ and $>30 \mathrm{~kg} / \mathrm{m}^{2}, \mathrm{two}$ or \\
& more of the following; high blood ammonia $(>80 \mathrm{mmol} / \mathrm{L})$, high arterial lactate $(>2 \mathrm{mmol} / \mathrm{L}), \mathrm{meta}-$ \\
& bolic acidosis $(\mathrm{pH}>7.2)$, hypoglycaemia $(<40 \mathrm{mg} / \mathrm{dl})$
\end{tabular}

Interventions Intervention group treated with MAD (20g carbohydrate per day) for 6 months

Control arm receive normal diet with no dietetic input for 6 months, following which MAD can be offered

$\begin{array}{ll}\text { Outcomes } & \text { Primary outcome } \\ \text { - Greater than } 50 \% \text { seizure reduction at } 6 \text { months }\end{array}$


CTRI/2015/07/006048 (Continued)

\section{Secondary outcomes}

- Rate and characteristics of short-term adverse events while on MAD

- Rate of withdrawal from the MAD diet during the study period and reasons for withdrawal

- Change in quality of life of both group during the study period

\begin{tabular}{ll}
\hline Starting date & $18 / 08 / 2015$ \\
\hline Contact information & manjari2tripathi@gmail.com \\
\hline Notes & Recruitment expected to be complete June 2018 \\
\hline
\end{tabular}

\section{Hulshof 2014}

Trial name or title

\section{Methods}

Participants
The modified Atkins diet in patients with drug-resistant epilepsy and severe intellectual disability design of a randomized controlled trial
A single-centre, parallel, unblinded randomised controlled trial

Aimed to recruit 54 people, aged $>18$ years, adults with drug-resistant epilepsy that was controlled by 2 AEDs. Included participants must have had $\geq 2$ seizures/month and have moderate-to-severe intellectual disability. Potential participants were excluded if they had undergone epilepsy surgery in the last 6 months or were awaiting surgery; underwent implantation of vagal nerve stimulation in the last 6 months; have used the MAD or KD for $>7$ days in the last year
Intervention group treated with the MAD for at least 4 months, with a total follow-up of at least 6 months

Control group comprised a waiting list in which participants can begin the MAD diet after the 4month trial period, the control group can be started on the MAD as well, in which efficacy, tolerability and safety will also be evaluated

Primary outcome
- Number of responders 4 months after randomisation, compared between the intervention and
the control group. Responder is defined by $>50 \%$ reduction in seizure frequency
Secondary outcomes
- Retention of the diet; change in daily functioning; feasibility of the MAD in this population and
setting; adverse events attributable to the MAD; predictive factors of efficacy of the diet

\section{Starting date}

Contact information

Notes
8 January 2014

H.M. Hulshof-3@umcutrecht.nl

On 28 July 2015, the study authors reported that this trial was ongoing and was now recruiting from an additional site. They expect to end recruitment at the end of July 2016 . No further update was received from the study authors for this update.

\section{NCT02708030}

Trial name or title

Dietary Therapy In Epilepsy Treatment (DIET-Trial): a randomised non-inferiority trial comparing KD, MAD \& LGIT for drug-resistant epilepsy (DIET) 
NCT02708030 (Continued)

Methods

A randomised, parallel, unblinded randomised control trial
Aimed to recruit 165 people, aged 1 to 15 years, with drug-resistant epilepsy (defined as seizure frequency $>4$ per month, and treatment failure of 2 or more AEDs), willing to attend regular follow-up. Potencial participants were excluded if they had surgically remediable causes of epilepsy, proven inborn errors of metabolism, previously received a KD (KD, MAD, LGIT), known case of chronic kidney disease, chronic liver disease/gastrointestinal illness, chronic heart disease or chronic respiratory illness

\begin{tabular}{ll}
\hline Interventions & Comparison of 3 types of KD; 4:1 KD, MAD, LGIT over a 24-week period (6 months) \\
\hline Outcomes & Primary outcome \\
- Percentage change in seizure frequency after 24 weeks of dietary therapy as compared to base- & line, in the KD versus MAD arm and in the KD versus LGIT arm \\
Secondary outcomes & Percentage change in seizure frequency after 24 weeks of dietary therapy as compared to base- \\
line, in the MAD versus LGIT arm \\
- Proportion of patients who achieve > 50\% seizure reduction from baseline at 24 weeks after diet \\
initiation \\
- Estimated behaviour change, as measured by Childhood behavior checklist in each of three arms \\
at baseline, 12 weeks and 24 weeks after dietary therapy \\
- Estimated cognition change, as assessed by Vineland Social Maturity Scale in each of three arms \\
at baseline, 12 weeks and 24 weeks after dietary therapy \\
- Evaluate gastrointestinal adverse events (diarrhoea, constipation and vomiting) assessed by \\
parental questionnaire in each of the three arms at baseline and six months after therapy \\
- Evaluate change in serum levels of micronutrients (e.g. copper, zinc, retinol and vitamin E) by \\
laboratory testing in each of three arms at baseline and six months after therapy \\
- Evaluate omega-3 polyunsaturated fatty acid levels and correlate it with change in seizure fre- \\
quency
\end{tabular}

\begin{tabular}{ll}
\hline Starting date & April 2016 \\
\hline Contact information & Professor Sheffali Gulati, All India Institute of Medical Sciences, New Delhi \\
\hline Notes & Unable to contact author \\
\hline
\end{tabular}

AED: antiepileptic drug; BMI: body mass index; KD: ketogenic diet; MAD: modified Atkins diet.

\section{AP PEN DICES}

\section{Appendix 1. Cochrane Epilepsy Group Specialized Register search strategy}

\#1 MeSH DESCRIPTOR Diet Therapy Explode All

\#2 MeSH DESCRIPTOR Fasting Explode All

\#3 ketogenic* or diet? or dieting

\#4 \#1 OR \#2 OR \#3

\#5 INREGISTER and >30/03/2015:CRSCREATED

\#6 \#4 AND \#5 


\section{Appendix 2. CENTRAL via CRSO search strategy}

\#1 MESH DESCRIPTOR Epilepsy EXPLODE ALL TREES WITH QUALIFIERS DH

\#2 MESH DESCRIPTOR Seizures EXPLODE ALL TREES WITH QUALIFIERS DH

\#3 \#1 OR \#2

\#4 MESH DESCRIPTOR Diet Therapy EXPLODE ALL TREES

\#5 MESH DESCRIPTOR Fasting EXPLODE ALL TREES

\#6 (ketogenic* or diet? or dieting):TI,AB,KY

\#7 \#4 OR \#5 OR \#6

\#8 (epilep* OR seizure* OR convuls*):TI,AB,KY

\#9 MESH DESCRIPTOR Epilepsy EXPLODE ALL TREES

\#10 MESH DESCRIPTOR Seizures EXPLODE ALL TREES

\#11 \#8 OR \#9 OR \#10

\#12 \#7 AND \#11

\#13 \#3 OR \#12

\#14 * NOT INMEDLINE AND 30/03/2015 TO 11/04/2017:CD

\#15 \#13 AND \#14

\section{Appendix 3. MEDLINE search strategy}

This strategy is based on the Cochrane Highly Sensitive Search Strategy for identifying randomised trials published in the Cochrane Handbook for Systematic Reviews of Interventions (Lefebvre 2011).

1. exp Epilepsy/dh [Diet Therapy]

2. exp Seizures/dh [Diet Therapy]

3. 1 or 2

4. exp Diet Therapy/

5. exp Fasting/

6. (ketogenic\$ or diet? or dieting).tw.

7.4 or 5 or 6

8. exp Epilepsy/

9. exp Seizures/

10. (epilep\$ or seizure\$ or convuls\$).tw.

11.8 or 9 or 10

12. exp *Pre-Eclampsia/ or exp *Eclampsia/

13. 11 not 12

14. 7 and 13

15. 3 or 14

16. (randomized controlled trial or controlled clinical trial or pragmatic clinical trial).pt. or (randomi?ed or placebo or randomly).ab. 
17. clinical trials as topic.sh.

18. trial.ti.

19. 16 or 17 or 18

20. exp animals/ not humans.sh.

21. 19 not 20

22. 15 and 21

23. limit 22 to ed=20150330-20170411

24. 22 not (1\$ or $2 \$)$.ed.

25.24 and ( $2015 \$$ or $2016 \$$ or $2017 \$$ ).dc.

26. 23 or 25

27. remove duplicates from 26

\section{Appendix 4. ClinicalTrials.gov search strategy}

epilepsy AND diet | Studies received on or after 03/30/2015

\section{Appendix 5. WHO International Clinical Trials Registry Platform (ICTRP) search strategy}

epilepsy AND diet NOT NCT*

Trials registered on or after 30/03/2015 selected manually

WHAT'S NEW

\begin{tabular}{lll}
\hline Date & Event & Description \\
\hline 11 April 2017 & New search has been performed & $\begin{array}{l}\text { We updated the searches on 11 April 2017 and included four new } \\
\text { studies (Lambrechts 2017; Kim 2016; Singh 2015; Zare 2017) }\end{array}$ \\
\hline 11 April 2017 & $\begin{array}{l}\text { New citation required but conclusions } \\
\text { have not changed }\end{array}$ & Conclusions are unchanged \\
\hline
\end{tabular}

\section{H I S T O R Y}

Protocol first published: Issue 1, 2000

Review first published: Issue 3, 2003

\begin{tabular}{lll}
\hline Date & Event & Description \\
\hline 30 March 2015 & New search has been performed & Searches updated 30 March 2015 \\
\hline 30 March 2015 & $\begin{array}{l}\text { New citation required but conclusions } \\
\text { have not changed }\end{array}$ & $\begin{array}{l}\text { Three new studies (El-Rashidy 2013; Raju 2011; Sharma 2013) } \\
\text { have been included. Conclusions are unchanged }\end{array}$ \\
\hline 28 May 2012 & Amended & New Summary of Findings table added \\
\hline 28 January 2012 & $\begin{array}{l}\text { New citation required but conclusions } \\
\text { have not changed }\end{array}$ & Review updated \\
\hline
\end{tabular}




\begin{tabular}{lll}
\hline Date & Event & Description \\
\hline 28 January 2012 & New search has been performed & $\begin{array}{l}\text { This review has been updated. Four new RCTs have been includ- } \\
\text { ed. Seven prospective studies and four retrospective studies } \\
\text { were also identified. }\end{array}$ \\
\end{tabular}

\section{CONTRIBUTIONS OF AUTHORS}

Kirsty J Martin-McGill was responsible for the update of this review.

Cerian $\mathrm{F}$ Jackson provided support for the update of this review.

Rebecca Bresnahan provided support for the update of this review.

Robert G Levy provided expert opinion and feedback.

Paul N Cooper provided expert opinion and feedback.

\section{DECLARATIONS OF INTEREST}

KM: receives PhD funding from Vitaflo (International) Ltd. However, Vitaflo did not contribute to or influence this review.

CJ: none known

RB: none known

RL: none known

PC: none known

\section{SOURCES OF SUPPORT}

\section{Internal sources}

- No sources of support supplied

\section{External sources}

- National Institute for Health Research (NIHR), UK.

This review update was supported by the NIHR, via Cochrane Infrastructure funding to the Epilepsy Group. The views and opinions expressed therein are those of the authors and do not necessarily reflect those of the Systematic Reviews Programme, NIHR, National Health Service (NHS) or the Department of Health.

\section{DIFFERENCES BETWEEN PROTOCOL AND REVIEW}

The methods, results, discussion, conclusion and recommendation sections have been updated due to the addition of new studies. This is the second title change since the protocol was published.

\section{INDEX TERMS}

\section{Medical Subject Headings (MeSH)}

Diet, Carbohydrate-Restricted [methods]; Diet, Ketogenic [adverse effects] [ ${ }^{*}$ methods]; Dietary Carbohydrates [ ${ }^{*}$ administration \& dosage]; Dietary Fats [*administration \& dosage]; Drug Resistant Epilepsy [ ${ }^{*}$ diet therapy]; Intention to Treat Analysis; Prospective Studies; Randomized Controlled Trials as Topic; Retrospective Studies

\section{MeSH check words}

Adolescent; Child; Humans 